\title{
Proxy Contests: A Study in Shareholder Sovereignty
}

\author{
Frank D. Emerson* and \\ Franklin C. Latcham**
}

TN NOVEMBER 1950 a development of lasting significance to shareholders took place-the successful conclusion of efforts by the Protest Committee of Non-Management and Independent Stockholders of The SparksWithington Company in electing its slate of five of the company's nine directors and in winning shareholder approval of two of its three proposals for corporate action. ${ }^{1}$ It was asserted that, in addition to being the first occasion on which a "grass roots" or small-stockholders committee of a New York Stock Exchange listed industrial company had been able to prevail over the management in a proxy contest, ${ }^{2}$ the Sparks-Withington contest afforded not only a number of interesting examples of how the Securities and Exchange Commission's proxy rules in general promote corporate or shareholder democracy, ${ }^{3}$ but also specifically demonstrated that the SEC's proxy rules may likewise make an effective contribution to our society by either inspiring present management to provide, or affording a medium for obtaiming elsewhere, the vigorous and faithful corporate leadership so essential to the growth and survival of our capitalistic democracy. ${ }^{4}$

* Interpretative Attorney for the Cleveland Regional Office of the Securities and Exchange Commission, and Lecturer in Law, Western Reserve University.

** Associate Professor of Law, Western Reserve University.

The Securities and Exchange Commission, as a matter of policy, disclaims responsibility for any private publication by any of its employees. The views expressed herein are those of the authors and do not necessarily reflect the views of the Securities and Exchange Commission or of Emerson's colleagues on the staff of the Commission.

1 See Emerson and Latcham, Further Insight Into More Effective Stockholder Participation: The Sparks-Withington Proxy Contest, 60 YALE L. J. 429 (1951).

$2 I d$. at 430.

8 The SEC has stated that its proxy rules "are probably the most useful of all the disclosure devices established by our [its] various acts and represent an effective contribution to corporate democracy." Report of the SEC, Proposal to SAFEgUaRd INVEstors IN UNREgistered Securities, H. R. Doc., No. 672, 79th Cong., 2d Sess. 18 (1946), and supplemented by a second report transmitted to Congress in connection with the Frear Bill, S.2408, as announced in ExCHANGE ACT RELEASE No. 4399 (Jan. 9, 1950). All releases cited, unless otherwise noted, are SEC releases.

"Corporate Democracy" is the 1952-53 topic of the Virginia Law Weekly, published by the University of Virginia, Department of Law, Dicta column, and the articles furnished by some 24 persons invited to contribute will appear as a symposium in a bound volume to be published this autumn. The writers' article appeared in two installments as Emerson and Latcham, Corporate Democracy; SEC's Proxy Regulation, VIRGINIA LAW WeEkIy Dicta, Vol. V, Nos. 8 and 9 (1952).

4 Supra note 1 , at 430 . 
The passage of two additional years since the Sparks contest and the non-management proxy solicitations that have taken place during that period under the proxy regulation have provided added experience against which to examine and test further the regulation's prospects for promoting shareholder democracy and progressive corporate leadership. ${ }^{5}$ Consequently, the writers have surveyed all non-management proxy statements and soliciting material filed with the SEC during 1951 and 1952, together with other related data, and have undertaken to report the results in the balance of this article. ${ }^{\circ}$ Comments and suggestions stimulated by the experience gained will be found in the "Conclusion."

\section{INTRODUCTORY CASE STUDY DATA}

Before surveying the 1951-52 material, however, a brief summary of the Sparks contest will be helpful, for it affords both an introduction by way of independent case study to the various principal elements involved in a proxy contest and also a model against which to view the comparative data to be presented with reference to the 1951-52 non-management proxy solicitations. ${ }^{8}$ At the time of the proxy contest, the Sparks-Withington

The SEC proxy rules, designated Regulation X-14, consist of Rules X-14A-1 through $\mathrm{X}-14 \mathrm{~A}-10$ and Schedule $14 \mathrm{~A}$, Items 1 through 21 . Regulation $\mathrm{X}-14$ has as its statutory basis Section 14(a) of the Securities Exchange Act of 1934, 15 U.S.C. 78n(a), Section 12 (e) of the Public Utility Holding Company Act of 1935, 15 U.S.C. 79, and Section 20(a) of the Investment Act of 1940, 15 U.S.C. 80a-20 (1946).

For an analysis of the proxy regulation, see Emerson and Latcham, SEC Proxy Regullation; Steps Toward More Effective Stockholder Participation, 59 YALE L. J. 635 (1950) and Friedman, SEC Regulation of Corporate Proxies, 63 HAarv. L. REv. 796 (1950). On December 11, 1952 the SEC announced its first amendments to the proxy regulation since 1948, mandatorily effective as to proxy solicitations commenced under X-14 on or after February 1 , 1953. See Exchange Act ReIrase No. 4775 (Dec. 11, 1952), and compare the proposed amendment contained in Excrange Act Release Nos. 4668 (Jan. 31, 1952), 4729 (July 10, 1952), and 4765 (October 10, 1952). See also Exchange Act Release No. 4809 (March 9, 1953), announcing SEC's determination not to adopt the Octoher 10, 1952 X-14A-3 proposal.

${ }^{6}$ The method employed in making the survey was as follows: Requests were mailed during December 1952 to the persons who filed non-management proxy statements with the SEC during 1951 and 1952 and to the presidents of the 47 of the 48 companies mvolved advising of the undertaking of the survey, and seeking from each copies of the proxy statements, proxy forms or ballots, and other proxy soliciting material. Data on expenses for use on a statistical or tabulatory basis was also requested, confidential treatment being assured, if desired, together with an indication of the votes for and against the proposals and/or director nominees submitted. Comments as to the operation of the proxy regulation were likewise invited.

Several weeks later similar follow-up letters were mailed, and in March 1953, due to failures to respond, it was necessary to purchase from the SEC at the SEC Rule of Practice XIII(j) rate of $15 \xi$ per page, or an aggregate of about $\$ 30$, non-management proxy statements and soliciting material relating to 19 or $40 \%$ of the 48 companies involved. Reference was also made to Standard Corporation Records and Moody's Statistical services, as well as to newspapers, magazines and periodicals, etc.

7 Infra, pp. 431-38.

8 Unless otherwise indicated the introductory information relating to the Sparks-Withington proxy contest is summarized from the writers' article, cited supra note 1, presenting a detailed case study of the contest, and in particular from that article pp. 431-33. 
Company, originally a Michigan corporation but rechartered under Ohio law in 1916, had assets and sales of approximately $\$ 9$ and $\$ 17$ million, respectively, 2,118 employees, and was engaged in the manufacture of television and radio sets and automobile parts, principally horns. Its common stock, listed and registered on the New York Stock Exchange, was held of record by approximately 5,000 persons, and estimated as being beneficially owned by approximately 8,500 persons, all of whom were entitled to vote their shares cumulatively under the mandatory cumulative voting provisions of the Ohio Corporation Act. ${ }^{9}$ The Protest Committee of NonManagement and Independent Stockholders owned only a little more than $1 \%$ of the outstanding common but this was slightly more than the management's meager common stock holdings of somewhat less than $1 \%$. By letter dated August 29, 1950, the Committee's chairman submitted three proposals for corporate action to the company president as permitted under Rule X-14A-8. ${ }^{10}$ The committee then filed preliminary copies of a proxy statement with the SEC on September 22, 1950, and after SEC authorization to use the proxy statement as amended, commenced soliciting proxies on October 6,1950, for the annual meeting scheduled for nearly three weeks later, on October 25, 1950.

The Protest Committee's proxy statement, dated October 2, 1950, listed six nominees for the company's nine directorships. These included the committee chairman, a Certified Public Accountant and president of the Sparks-Withington Company since the proxy contest; four business men, one the vice-president of a lock company, two others presidents respectively of a foundry and an abrasives company, and one a radio and television dealer; and the sixth, a professor of engineering on the faculty of the University of Michigan. The committee employed five mailings, amounting to the equivalent of approximately 11 pages $81 / 2$ by 11 inches in size. The second of the five mailings in particular made reference to and expanded upon the committee chairman's three Rule X-14A-8 proposals carried in the management's proxy statement. Three of the five mailings were merely penny postal cards, but carried dramatically drafted text mailed to shareholders during the closing stages of the Sparks contest.

\footnotetext{
9 OHIO GEN. CODE $\$ 8623-50$ a (1952) made cumulative voting mandatory in Ohio upon the giving by a shareholder of the prescribed written notice that cumulative voting is desired.

10 Rule X-14A-8, of the SEC's proxy regulation, stated generally, gives a security holder the privilege of obligating the management to imclude in the management's proxy statement his proposal if it is a "proper subject for action by security holders," and also, if the management opposes the proposal, a 100 word supporting statement by the security lolder, together with the shareholder-proponent's name and address. For an article interpreting X-14A-8 and surveying all proposals submitted under X-14A-8 during the four-year period 1948-1951, see Emerson and Latcham, 19 U. of CHI. L. REv. 807 (1952). The article was one of ten contained in the cited law review's Summer 1952 Issue, which took the form of an excellent symposium on "The Modern Corporation."
} 
Committee objectives, in addition to election of six of the nine company directors; included, of course, the three proposals for action submitted to the management pursuant to X-14A-8. Moreover, the three X-14A-8 proposals, as will be seen, effectively introduced and buttressed the issues urged in the committee's proxy material in support of the contest for the six directorships. Similarly, the technique of utilizing X-14A-8 to place the proposals and indirectly related directorship issues before fellow shareholders gave assurance that these matters would be available for consideration at the same sitting at which the shareholders read the management's proxy statement relating to the management's nine nominees and its proposals.

The three X-14A-8 proposals, briefly stated, were: (1) amendment of the company's by-laws to provide that shareholders rather than the directors select at each annual meeting a firn of independent public accountants to audit and certify to the annual financial statements; (2) authorization to the directors to limit officers' salaries to $\$ 25,000$ per year, unless (a) the officer owned at least 2,000 common shares, or (b) the company's net consolidated earnings after taxes exceeded $6 \%$ of its combined capital, surplus, and surplus reserves; and (3) election by shareholders of a three-man committee to investigate and report on eight specified matters. The areas of intended investigation included in the third proposal were: (1) advisability of dissemination to stockholders of condensed quarterly or semi-annual financial statements, (2) scrutiny of the services rendered by and compensation paid to the president's brother as vice-president and to the president's son as an employee, (3) study of the business and other connections of company officers and the former export manager with six kindred business enterprises in which one or more of then were interested, (4) surveying of the company's dealership relations and its operation generally as compared to competitors, (5) review of the necessity for constructing a new office building within three blocks of an existing one which was only partially occupied, and (6) ascertaining whether investment advisers and brokers were reluctant to encourage investment in the company's common stock. ${ }^{11}$

Enumeration of the issues urged by the committee in its own proxy statement and soliciting material emphasizes how closely the three $\mathrm{X}-14 \mathrm{~A}-8$ proposals and the areas they covered supported the issues to be relied upon in the contest for election of the committee's six nominees for directorships. These directorship issues encompassed (1) low earnings and dividends,

\footnotetext{
11 For the text of the X-14A-8 proposals, see The Sparks-Withington Company 1950 Management proxy statement. This and all other cited proxy material filed with SEC can be obtained from its Washington, D.C. office at the $15 \xi$ per page photocopy rate prescribed in SEC Rule of Practice XIII(j).
} 
(2) directors' small common stock ownership, (3) management's other business interests, (4) comparison of sales and dividends with salaries, bonuses, and pensions, (5) management's engaging of a firm of paid proxy solicitors, (6) stale, fearful, dead-on-the-vine management, (7) burden of the $6 \%$ preferred held by management, (8) shareholder board representation, (9) questions to and answers by the company president regarding operations, (10) pressured withdrawal of one of the committee's nominees, (11) comparison of company's and competitors' dividends, and (12) "time for a change."12

While members of management, company employees, and a New York City firm of specially engaged paid proxy solicitors carried on personal solicitation of proxies in favor of the management, the committee's personal solicitation, by means of a stockholder's list obtained from the company as provided by Ohio law, ${ }^{13}$ was carried on by the committee members, and in particular by the committee chairman's friends, wife, brother, and the chairman himself, who flew his own privately owned, second-hand Beechcraft Bonanza airplane between the various midwestern cities where the bulk of the common stock was held. Management's solicitation expenses totaled $\$ 51,165$. The committee's were approximately $\$ 6,000$, representing the entire cash savings of the committee chairman. ${ }^{14}$ By these means the votes of approximately $70 \%$ of the outstanding common shares were brought out. Initially somewhat more than $55 \%$ of the shares voted were in support of the committee, but expensive proxy switching techniques employed by management reduced the committee's margin to a narrow $51 \%$. This, however, was sufficient to elect all five of the committee's remaining

12 The issues urged in support of the contest for directorships, as well as further data in support of the X-14A-8 proposals, will be found in The Sparks-Withington Company 1950 Non-Management Proxy Statement dated October 2, 1950 and in its first follow-up soliciting material, dated October 16, 1950. Preliminary copies of proposed proxy statements and forms of prosy inust under Rule X-14A-6(a) be filed with the SEC's Washington, D.C. office in triplicate, together with any other soliciting material to be furnished to security loolders concurrently, at least ten days prior to the date definitive copies are first sent or given to security Lolders, or such shorter period prior to that date as the Commission may authorize upon a showing of good cause. Additional or follow-up material must under X-14A-6(b) be similarly filed at least two days (exclusive of Saturdays, Sundays or holidays) prior to their use or such shorter period as the Commission may authorize for good cause. Definitive proxy material nust be filed with the SEC and the appropriate exchange pursuant to X-14A-6(c) no later than the date it is first sent or given to security lolders.

13 Onto GeN. CODE $\S 8623-63$ (1940) provides that lists of shareholders shall be open to the inspection of shareholders.

14 For articles on proxy contest expenses, see Latcham and Emerson, Proxy Contest Expenses and Shareholder Democracy, 4 WEsT. REs. L. REv. 5 (1952) and Friedman, Expenses of Corporate Proxy Contests, 51 CoL. L. Rev. 951 (1951). 
nominees and to carry the two of the three $\mathrm{X}-14 \mathrm{~A}-8$ proposals drawn as recommendations or suggestions rather than as a by-law amendment, but resulted in defeat of the proposed by-law amendment regarding shareholder election of auditors, because of its failure to win a majority of the shares outstanding. ${ }^{15}$ Notwithstanding the committee's success, various of the formidable obstacles encountered appeared to pose sigmificant problems and certain remedies were suggested. ${ }^{10}$

\section{SURVEY BACKGROUND DATA}

In addition to the insight gained from case and model studies, understanding is also aided by consideration of the background or context in which events take place and in which law and regulation must operate. It therefore appears advisable, prior to surveying the immediate aspects of the 1951-52 non-management proxy solicitations, to isolate and examine background economic, statistical and other pertinent information developed by the survey. The more relevant among such data include: (1) number of non-management proxy statements filed during the past ten years; (2) assets in dollars of the 48 companies involved; (3) sales in dollars of the companies; (4) industries in which the companies operated; (5) states of incorporation and cumulative voting rights; (6) number of shareholders of record, and whether an annual or special meeting was involved. Insofar as these matters entail statistics they will be presented in terms of aggregates, averages or means, first quartiles, medians, third quartiles, and modes or modal classes.

\section{Number of Non-Management Proxy Statements}

During 1951 and 1952 there were filed with the SEC 1,791 and 1,803 proxy statements, respectively, of which 25 or $1.39 \%$ and 27 or $1.49 \%$ were non-management proxy statements, respectively. ${ }^{17}$ The 1951 and 1952 percentage of non-management filings vary only slightly from the percentages that have obtained over the ten-year period 1943-1952, as is seen by

15 As to the significance of $X-14 A-8$ proposals drawn as recommendations or suggestions and those drawn as contemplated by-law amendments, see Emerson and Latcham, supra note 10 at 809-11.

10 Emerson and Latcham, supra note 1 at 449, and see Exchange Acr ReLEAse No. 4775 (Dec. 11, 1952). Sparks-Withington post proxy contest average annual sales for its three fiscal years ended June 30,1953 , were $55 \%$ over the average for the five prior fiscal years ended June 30, 1950.

17 The 1952 figures were obtained from the SEC's Division of Corporation Finance, and are the figures submitted to the Bureau of the Budget. The 1951 figures appear at SEC 18th Ann. Rep. (1953). The Gilbert brothers' proxy statement is excluded from the 1951 and 1952 figures. As to the Gilberts see Emerson and Latcham, supra note 10 at 830. 
comparing them with the ten-year average and median percentages. ${ }^{18}$ Moreover, there has been relatively little difference at any time in the percentage of non-management filings over the ten years. ${ }^{19}$ And during the past six years the percentage has been lower than the percentage of management proxy statements which have carried security holder proposals, as contemplated by X-14A-8, due, of course, to increased use of the proposal rule. ${ }^{20}$

Contrary to suggestions sometimes made, the figures referred to clearly indicate that opposition groups have not used the proxy regulation in any

\begin{tabular}{ccccc}
\hline 18 & \multicolumn{5}{c}{} & & \\
\hline Year & $\begin{array}{c}\text { Number of } \\
\text { Proxy } \\
\text { Statements } \\
\text { Filed }\end{array}$ & $\begin{array}{c}\text { Number of } \\
\text { Non-Mianage } \\
\text { ment Proxy } \\
\text { Statements }\end{array}$ & $\begin{array}{c}\text { \% of Non- } \\
\text { Management } \\
\text { Proxy } \\
\text { Statements }\end{array}$ & $\begin{array}{c}\text { \%o of Management } \\
\text { Proxy Statements } \\
\text { to Carrying } \\
\text { of X-14A-8 } \\
\text { Proposals }\end{array}$ \\
\hline 1952 & 1,803 & 27 & 1.49 & 2.4 \\
1951 & 1,791 & 25 & 1.39 & 2.2 \\
1950 & 1,737 & 24 & 1.38 & 3.3 \\
1949 & 1,653 & 28 & 1.69 & 2.6 \\
1948 & 1,677 & 29 & 1.72 & 2.3 \\
1947 & 1,645 & 32 & 1.94 & 2.3 \\
1946 & 1,685 & 21 & 1.24 & 1.1 \\
1945 & 1,594 & 24 & 1.56 & 0.1 \\
1944 & 1,550 & 27 & 1.74 & 1.3 \\
1943 & 1,467 & 31 & 2.11 & 1.8 \\
Average & 1,660 & 26.8 & 1.62 & 1.9 \\
Median & 1,665 & 27 & 1.63 & 2.3 \\
\hline
\end{tabular}

The 1950 figures are from SEC 17th ANN. ReP. (1952) 44; the 1947-49, SEC 16th ANN. REP. (1951) 42; 1944-46, SEC 15th ANn. Rep. (1950) 48; 1943, SEC 13th ANN. REP. (1944) 42 ; and the sources of the 1951 and 1952 figures are indicated supra note 17.

19

\begin{tabular}{lcccc}
\hline Measurement & $\begin{array}{c}\text { Number of } \\
\text { Proxy } \\
\text { Statements } \\
\text { Filed }\end{array}$ & $\begin{array}{c}\text { Number of } \\
\text { Non-Manage- } \\
\text { ment Proxy } \\
\text { Statements }\end{array}$ & $\begin{array}{c}\text { \% of Non- } \\
\text { Mianagement } \\
\text { Proxy } \\
\text { Statements }\end{array}$ & $\begin{array}{c}\text { \% of Management } \\
\text { Proxy Statements } \\
\text { to Carrying } \\
\text { of X-14A-8 } \\
\text { Proposals }\end{array}$ \\
\hline Average & 1,660 & 26.8 & 1.62 & 1.94 \\
First Quartile & 1,594 & 24 & 1.39 & 1.30 \\
Median & 1,665 & 27 & 1.63 & 2.25 \\
Third Quartile & 1,737 & 29 & 1.74 & 2.40 \\
\hline
\end{tabular}

While the synonymous meanings of the terms "average" or "arithmetic mean" are quite commonly understood outside of mathematical and statistical circles, the terms "median," "first quartile," "third quartile," and "mode" or "modal class" are not so well known. The median is the middle one of a set of figures or other measurements arranged in order of magnitude, or if there is no middle one it is the average or mean of the middle two. The median separates the set or series into two separate groups. The middle or median item of the lower group is the first quartile; the middle item of the upper, the third quartile. The mode, meaning the fashion, in a collection of figures or other measurements is the item, if any, occurring more often than any other. If no particular item is duplicated the collection may be divided into bands of equal scope, and the band within which the largest number of items in the collection is found is the modal class. See James and James, Mathematics Drctionary (1949) and Simpson, Pierarax \& Crenshaw, Mathematics of Finance 147 (1938).

20 Supra note 18 table, cf. its col. 4 with its col. 5. 
substantial measure as an instrument for harassment generally of managements and companies subject to SEC's proxy regulation.

\section{Assets in Dollars of 48 Companies Involved}

The total assets of the 48 companies immediately prior to the respective solicitations and in respect of which non-management proxy statements were filed during 1951 and 1952 amounted to over $\$ 17$ billion. ${ }^{21}$ However, this figure is disproportionately increased by the 1952 non-management proxy solicitation involving the American Telephone and Telegraph Company, which as of December 31,1951, had assets of approximately $\$ 123 / 4$ billion and was the only billion dollar company involved. When AT\&T is removed from the 1951-52 total and the 1952 figures the result is about $\$ 23 / 4$ billion for 1952 and $\$ 41 / 4$ billion for 1951-52.22 Moreover, when this adjustment is niade the 1951 sum of total assets affected of about $\$ 11 / 2$ billion is considerably more comparable to the 1952 sum of adjusted total assets affected in the amount of approximately $\$ 23 / 4$ billion.

\begin{tabular}{|c|c|c|c|c|c|c|c|}
\hline \multicolumn{4}{|c|}{21 All 48 companies } & \multicolumn{4}{|c|}{47 companies excluding A.T.\&T. } \\
\hline \multicolumn{2}{|r|}{ Year } & $\begin{array}{l}\text { Number of } \\
\text { Companies }\end{array}$ & \multicolumn{2}{|c|}{$\begin{array}{c}\text { Assets } \\
\text { (000 omitted) }\end{array}$} & Year & $\begin{array}{l}\text { Number of } \\
\text { Companies }\end{array}$ & $\begin{array}{c}\text { Assets } \\
(000 \text { omitted })\end{array}$ \\
\hline \multicolumn{2}{|r|}{1950} & 24 & \multicolumn{2}{|c|}{$\$ 1,551,753$} & 1950 & 24 & $\$ 1,551,753$ \\
\hline \multicolumn{2}{|r|}{1951} & 24 & \multicolumn{2}{|c|}{$15,519,021$} & 1951 & 23 & $2,744,806$ \\
\hline \multicolumn{2}{|r|}{ Total } & 48 & \multicolumn{2}{|c|}{$\$ 17,070,774$} & Total & 47 & $\$ 4,296,559$ \\
\hline \multicolumn{8}{|c|}{${ }^{22}$ Assets of 47 companies excluding A.T.\&T. (000 omitted) } \\
\hline Year & Average & \multicolumn{2}{|c|}{$\begin{array}{c}\text { First } \\
\text { Quartile }\end{array}$} & Median & \multicolumn{2}{|c|}{$\begin{array}{l}\text { Third } \\
\text { Quartile }\end{array}$} & $\begin{array}{l}\text { Mode or } \\
\text { Modal Class }\end{array}$ \\
\hline 1950 & $\$ 64,656$ & \multicolumn{2}{|c|}{$\$ 7,243$} & $\$ 18,501$ & \multicolumn{2}{|c|}{$\$ 49,490$} & $\begin{array}{l}\$ 379 \text { to } \\
\$ 35,365\end{array}$ \\
\hline 1951 & 114,991 & \multicolumn{2}{|c|}{3,991} & 16,198 & \multicolumn{2}{|c|}{67,574} & $\begin{array}{l}\$ 314 \text { to } \\
\$ 64,322\end{array}$ \\
\hline \multirow[t]{2}{*}{1950} & $\begin{array}{l}\text { RKO } \\
\text { Theatre } \\
\text { Corp. }\end{array}$ & \multicolumn{2}{|c|}{$\begin{array}{l}\text { Aluminum } \\
\text { Industries, } \\
\text { Inc. }\end{array}$} & $\begin{array}{l}\text { National } \\
\text { Airlines, } \\
\text { Inc. }\end{array}$ & \multicolumn{2}{|c|}{$\begin{array}{l}\text { Chicago, } \\
\text { Ind. \& } \\
\text { L. Ry. Co. }\end{array}$} & 15 companies \\
\hline & $\begin{array}{l}\text { Chicago } \\
\text { Great } \\
\text { Western } \\
\text { Ry. }\end{array}$ & $\begin{array}{l}\text { Uni } \\
\text { Boa } \\
\text { Car } \\
\text { Cor }\end{array}$ & $\begin{array}{l}\text { United } \\
\text { Board \& }\end{array}$ & $\begin{array}{l}\text { Houdaille } \\
\text { Hershey } \\
\text { Corp. }\end{array}$ & & & \\
\hline 1951 & $\begin{array}{l}\text { Phila- } \\
\text { delphia } \\
\text { Transport } \\
\text { Co. }\end{array}$ & \multicolumn{2}{|c|}{$\begin{array}{l}\text { Hydraulic } \\
\text { Press, } \\
\text { Brick Co. }\end{array}$} & $\begin{array}{l}\text { Phillips- } \\
\text { Jones } \\
\text { Corp. }\end{array}$ & \multicolumn{2}{|c|}{$\begin{array}{l}\text { Third Avenue } \\
\text { Transit } \\
\text { Corp. }\end{array}$} & 17 companics \\
\hline
\end{tabular}

The lower portion of the above table substitutes the names of the companies, or in one column the number of companies, represented by the asset dollar figures shown in the table's upper portion. The 151951 companies, comprising the 1950 assets nlodal class, with their respective assets, are:

(1) Merchants Petroleum Co., $\$ 379,000$.

(2) Sovereign Investors, Inc., $\$ 441,000$.

(3) American Bantanı Car Co., $\$ 1,043,000$.

(4) Hudson \& Manhattan R.R. Co., $\$ 1,897,000$.

(5) Illinois Zimc Co., $\$ 3,737,000$.

(6) Aluminum Industries, Inc., $\$ 6,715,000$.

(7) United Board \& Carton Corp., $\$ 7,770,000$. 
Inasmuch as the total assets of all the nation's manufacturing corporations at the end of 1951 are estimated at $\$ 144.8$ billion and at the end of 1950 at $\$ 126.3$ billion, ${ }^{23}$.it would appear that, even if all assets involved had been exclusively those of manufacturing companies, assets affected by non-management solicitations under the SEC's proxy rules, amounting to but $\$ 1.5$ billion or $1.19 \%$ and $\$ 15.5$ billion or $10.7 \%$ (including AT\&T) in 1950 and 1951, respectively, of manufacturing assets, comprised a very small proportion indeed of total business assets. A more precise percentage, although less inclusive, is obtained by totaling the assets of the manufacturing companies subject to non-management solicitations and comparing these sums with the assets of all manufacturing companies. When this is done it is found that the assets of the 12 or $50 \%$ of the 24 companies engaged in manufacturing and involved in 1951 non-management solicitations total to nearly $\$ 240$ million or about $12 \%$ of all assets affected by such solicitations, and amount to only approximately $.14 \%$ of all manufacturing assets. ${ }^{24}$ Similarly the assets of the 12 or $50 \%$ of the 24 companies engaged
(8) Lawrence Portland Cement, $\$ 7,893,000$.
(9) Ainsworth Mfg. Co., $\$ 9,394,000$.
(10) Scullin Steel Co., $\$ 10,344,000$.
(11) King-Seeley Corp., $\$ 12,399,000$.
(12) National Airlines, Inc., $\$ 16,502,000$.
(13) Houdaille Hershey Corp., $\$ 20,501,000$.
(14) Hawaiian Pineapple Co., Ltd., \$21,172,000.
(15) United Cigar Whelan Stores Corp., $\$ 28,271,000$.

The 171952 companies in the 1951 assets modal class with their assets are:

(1) British Type Investors, Inc., $\$ 314,000$.

(2) Automatic Steel Prod. Corp., $\$ 3,068,000$.

(3) Jim Brown Stores, Inc., $\$ 3,505,000$.

(4) Berghoff Brewing Corp., $\$ 3,745,000$.

(5) Colonial Airlines, Inc., $\$ 3,755,000$.

(6) United Dye \& Chemical Corp., $\$ 3,897,000$.

(7) Hydraulic Press Brick Co., $\$ 3,991,000$.

(8) Consolidated Royalty Oil Co., $\$ 4,906,000$.

(9) Kalamazoo Stove \& Furnace Co., $\$ 5,617,000$.

(10) Aluminum Industries, Inc., $\$ 7,696,000$.

(i1) Jacobs Co., F. L., $\$ 11,397,000$.

(12) Phillips-Jones Corp., $\$ 15,451,000$.

(13) Four Wheel Drive Auto Co., $\$ 16,945,000$.

(14) Eastern Sugar Assocs., \$18,189,000.

(15) Securities Investment $\mathrm{Co}$., $\$ 18,682,000$.

(16) Cornell-Dubilier Electric Corp., $\$ 21,581,000$.

(17) Pittsburgh Ry. Co., $\$ 49,640,000$.

${ }^{23}$ See SEC Statistical Series Release No. 1081 (May 4, 1952).

24 The 121951 manufacturing companies, with their assets, are:

(1) Merchants Petroleum Co., $\$ 379,000$.

(2) American Bautam Car Co., $\$ 1,043,000$.

(3) Illinois Zinc Co., $\$ 3,737,000$.

(4) Aluminun Industries Inc., $\$ 6,715,000$.

(5) United Board \& Carton Co., $\$ 7,770,000$.

(6) Lawrence Portland Cement Co., $\$ 7,893,000$.

(7) Ainsworth Mfg. Co., $\$ 9,394,000$.

(8) Scullin Steel Co., $\$ 10,344,000$.

(9) King-Seeley Corp., $\$ 12,399,000$.

(10) Houdaille Hershey Corp., $\$ 20,501,000$.

(11) Hawaiian Pineapple Co., $\$ 21,172,000$.

(12) Curtis Publishing Co., $\$ 88,267,000$. 
in inanufacturing and involved in 1952 non-management solicitations total to nearly $\$ 116$ million or about $4 \%$ of all assets (exclusive of AT\&T) affected by such solicitations, and amount to only approximately $.07 \%$ of all manufacturing assets. ${ }^{25}$ It therefore seems most unlikely that nonmanagement proxy solicitation under Regulation X-14 is significantly burdening the physical capacity of the nation.

\section{Sales in Dollars and Number of Employees of the Companies}

Sales, i.e. net sales, gross revenues, or income from investments, of the 48 companies immediately prior to the solicitations and in respect to which non-management proxy statements were filed during 1951 and 1952 amounted to about $\$ 51 / 4$ billion. ${ }^{26}$ However, this figure is also distorted by the 1952 non-management proxy solicitation involving the American Telephone \& Telegraph Company, which for the year ended December 31, 1951 had revenue of approximately $\$ 3.6$ billion and was the only billion dollar receipts company involved. When AT\&T is removed from the 1951-52 total and the 1952 figures the result is about $\$ 1.6$ billion for $1951-52$ and $\$ 928$ million for $1952 .{ }^{27}$ Again, when this adjustment is made the 1951

25 The 121952 manufacturing counpanies, with their assets, are:

(1) Automatic Steel Prod. Corp., $\$ 3,068,000$.

(2) Berghoff Brewing Corp., $\$ 3,745,000$.

(3) United Dye \& Chemical Corp., $\$ 3,897,000$.

(4) Hydraulic Press Brick Co., $\$ 3,991,000$.

(5) Consolidated Royalty Oil Co., $\$ 4,906,000$.

(6) Kalamazoo Stove \& Furnace Co., $\$ 5,617,000$.

(7) Aluminum Industries, Inc., $\$ 7,696,000$.

(8) Jacobs Co., F. L., $\$ 11,397,000$.

(9) Phillips-Jones Corp., $\$ 15,451,000$.

(10) Four Wheel Drive Auto Co., $\$ 16,945,000$.

(11) Eastern Sugar Associates, $\$ 18,189,000$.

(12) Cornell-Dubilier Electric Corp., $\$ 21,581,000$.

28 All 48 companies.

\begin{tabular}{|c|c|c|c|c|c|}
\hline Year & $\begin{array}{l}\text { Number of } \\
\text { Companies }\end{array}$ & $\begin{array}{c}\text { Sales } \\
\text { (000 omitted) }\end{array}$ & Year & $\begin{array}{l}\text { Number of } \\
\text { Companies }\end{array}$ & $\begin{array}{c}\text { Sales } \\
\text { (000 omitted) }\end{array}$ \\
\hline 1950 & 24 & $\$ 700,895$ & 1950 & 24 & $\$ 700,895$ \\
\hline 1951 & 24 & $4,567,868$ & 1951 & 23 & 928,406 \\
\hline Total & 48 & $\$ 5,268,763$ & Total & 47 & $\$ 1,629,301$ \\
\hline \multicolumn{6}{|c|}{${ }^{27}$ Sales of 47 companies excluding A.T.\&T. (000 omitted) } \\
\hline Year & Average & $\begin{array}{c}\text { First } \\
\text { Quartile }\end{array}$ & Median & $\begin{array}{c}\text { Third } \\
\text { Quartile }\end{array}$ & $\begin{array}{c}\text { Mode or } \\
\text { Modal Clas3 }\end{array}$ \\
\hline 1950 & $\$ 29,003$ & $\$ 6,417$ & $\$ 21,944$ & $\$ 44,287$ & $\begin{array}{r}\$ 31 \text { to } \$ 5,203 \\
\$ 5,203 \text { to } \$ 10,375\end{array}$ \\
\hline 1951 & 39,993 & 4,564 & 13,126 & 28,053 & $\$ 14$ to $\$ 25,948$ \\
\hline \multirow[t]{2}{*}{1950} & $\begin{array}{l}\text { King- } \\
\text { Seeley } \\
\text { Corp. }\end{array}$ & $\begin{array}{l}\text { Illinois } \\
\text { Zinc. Co. }\end{array}$ & $\begin{array}{l}\text { Chicago, In } \\
\text { \& St. Louis } \\
\text { Ry. Co. }\end{array}$ & $\begin{array}{l}\text { RKO } \\
\text { Theatre } \\
\text { Corp. }\end{array}$ & 10 companies \\
\hline & $\begin{array}{l}\text { Missouri- } \\
\text { Pacific } \\
\text { R.R. Co. }\end{array}$ & $\begin{array}{l}\text { Hudson- } \\
\text { Manhattan } \\
\text { R.R. Co. }\end{array}$ & $\begin{array}{l}\text { Ainsworth } \\
\text { Mfg. Co. }\end{array}$ & $\begin{array}{l}\text { Hawaiian } \\
\text { Pineapple } \\
\text { Co. }\end{array}$ & \\
\hline 1951 & $\begin{array}{l}\text { Cornell- } \\
\text { Dubilier } \\
\text { Electric Co. }\end{array}$ & $\begin{array}{l}\text { Jim Brown } \\
\text { Stores }\end{array}$ & $\begin{array}{l}\text { Intl. Rys. } \\
\text { of Cent'l } \\
\text { America }\end{array}$ & $\begin{array}{l}\text { Pittsburgh } \\
\text { Rys. Co. }\end{array}$ & 16 companies \\
\hline
\end{tabular}


sum of total sales affected of about $\$ 700$ million is substantially closer to the 1952 sum of adjusted total sales affected in the amount of approximately $\$ 928$ million.

Emphasis in recent years by accountants on the income or profit and loss statement as an analytical tool and the coincident evolving by economists of national income accounting both point up income as an especially important index. Gross national product was $\$ 284.2$ billion and $\$ 329.2$ in 1950 and 1951 respectively. ${ }^{28}$ Inasmuch as profits after taxes were $7.1 \%$ and $4.8 \%$ of the sales of manufacturing corporations in 1950 and $1951,{ }^{29}$

The lower portion of the above table substitutes the names of the companies, or in one column the number of companies, represented by the sales dollar figures shown in the table's upper portion. The 101951 companies comprising the $1950 \$ 31,000$ to $\$ 5,203,000$ modal class and the $\$ 5,203,000$ to $\$ 10,375,000$ modal class, with their respective sales, are:

(1) Sovereign Investors, Inc., $\$ 31,000$.

(2) Merchants Petroleum Co., $\$ 73,000$.

(3) American Bantam Car Co., $\$ 316,000$.

(4) Scullin Steel Co., $\$ 1,155,000$.

(5) Selected Industries, Inc., $\$ 3,049,000$.

(6) Illinois Zinc Co., $\$ 5,582,000$.

(7) Hudson Manhattan R.R. Co., \$7,251,000.

(8) United Board \& Carton Co., $\$ 7,962,000$.

(9) Lawrence Portland Cement Co., Inc., $\$ 8,539,000$.

(10) Aluminum Industries, Inc., $\$ 9,085,000$.

The 161952 compames in the 1951 modal class, with their sales, are:

(1) British Type Investors, $\$ 14,000$.

(2) Securities Investment Co., $\$ 139,000$.

(3) Consolidated Royalty Oil Co., $\$ 369,000$.

(4) United Dye \& Chemical Corp., $\$ 2,928,000$.

(5) Hydraulic Press Buick Co., $\$ 4,443,000$.

(6) Jim Brown Stores, Inc., $\$ 4,564,000$.

(7) Berghoff Brewing Corp., $\$ 4,764,000$.

(8) Automatic Steel Prod. Co., $\$ 5,402,000$.

(9) Colonial Airlines, Inc., $\$ 6,737,000$.

(10) Kalamazoo Stove \& Furnace Co., $\$ 9,679,000$.

(11) Eastern Sugar Associates, $\$ 11,142,000$.

(12) Int'I Rys. of Central Amer., $\$ 13,126,000$.

(13) Aluminum Industries, Inc., $\$ 13,267,000$.

(14) Four-Wheel Drive Auto Co., $\$ 18,002,000$.

(15) Jacobs Co., F. L., $\$ 20,402,000$.

(16) Phillips-Jones Corp., $\$ 24,673,000$.

28 The Econontrc Report of the President and The ANnuar Econontc Revirew by THE Councm of Econonnc Advisers (January 1953) 165 (Table B-1-Gross National Product or Expenditure, 1929-52).

29 The source of the $7.1 \%$ figure for 1950 profits after taxes as a percent of 1950 sales of manufacturing corporations is THE ECONOMIC REPORT OF THE PRESIDENT AND THE ANNUAL Economic REvIEW By THE COUNCII OF Economic Advisers (January 1952) 201. The comparable $4.8 \%$, 1951 figure is from The Econontic Report of the President and The Annuad Economic REVIEW BY THE CouncI OF Economic ADvisers (January 1953) 203.

Manufacturing corporations' 1950 sales and profits after taxes as a percent of sales were $\$ 181.9$ billion and $7.1 \%$ (SEC STATISTICAI SERIEs REx. No. 1081 (May 4, 1952). For 1951, although originally estimated at $\$ 212.2$ billion and $5.4 \%$, respectively, in the release just cited, they were more recently estimated at $\$ 245$ billion and $4.8 \%$ (SEC STATISTICAL SERIES REL. No. 1158 (May 11, 1953). Even on the basis first reported manufacturing profits after taxes were $12 \%$ lower in 1951 than in 1950, and were attributed to increased costs and higher income taxes. 1951 sales established a new annual record to that year end (Ibid.). 
respectively, and assuming for comparative purposes that such rates had obtained for all the companies involved in non-management solicitations in the respective years, ${ }^{30}$ indicated profits after taxes are $\$ 49.7$ million and $\$ 219.1$ inillion for the 48 companies (including AT\&T) in 1950 and $1951 .^{81}$ These estimated net profits after taxes amount respectively to $.01 \%$ and $.06 \%$ of gross national product for 1950 and 1951, with the result that non-manageinent solicitations under the SEC's proxy regulations obviously could not have had any appreciable effect on the nation's 1951 and 1952 production. $^{32}$

30 The assumption of percentage relationship of profits after taxes to sales must be considered in the context of two important diverse facts: (1) in both 1950 and 1951 the companies subject to non-management proxy statement filings included not only manufacturing companies, supra notes 24 and 25 , but also railroad, electric railway and bus, airline, utility, and investment companies et al. (see notes 36-38, 40 infra), and (2) the actual profits after taxes of the companies involved were frequently considerably lower than average, as is indicated by the fact that, in the instance of 19 or $39 \%$ of the 48 companies, low earnings (or dividends), i.e. profits after taxes, were specifically either an issue in the contest for directorships or the subject of a proposal. Moreover, low earnings and dividends as an issue or subject individually were one of the most frequently urged opposition complaints, accounting for 26 or $15 \%$ of the 161 issues or subjects presented to fellow security holders by the opposition (see infra p. 417).

${ }^{31} \$ 49.7$ million $=7.1 \%$ of $\$ 700,895,000$ and $\$ 219.1$ million $=4.8 \%$ of $\$ 4,567,868,000$.

Cf. supra note 24 .

$32 \$ 49,700,000 \div \$ 284,200,000,000=.01 \%$ for 1950 .

$\$ 219,100,000 \div \$ 329,200,000,000=.06 \%$ for 1951 .

Sales of the manufacturing companies were:

\section{1}

(1) Merchants Petroleum Co., $\$ 73,000$.

(2) American Bantanı Car Co., $\$ 316,000$.

(3) Scullin Steel Co., $\$ 1,155,000$.

(4) Illinois Zinc Co., $\$ 5,582,000$.

(5) United Board \& Carton Co., $\$ 7,962,000$.

(6) Lawrence Portland Cement Co., $\$ 8,539,000$.

(7) Aluminum Industries, Inc., $\$ 9,085,000$.

(8) King-Seeley Corp., $\$ 28,766,000$.

(9) Ainsworth Mfg. Co., $\$ 23,192,000$.

(10) Hawaiian Pineapple Co., $\$ 51,353,000$.

(11) Houdaille Hershey Corp., $\$ 70,450,000$.

(12) Curtis Publishing Co., $\$ 118,988,000$.

1952

(1) Consolidated Royalty Oil Co., $\$ 369,000$.

(2) United Dye and Chemical Corp., $\$ 2,928,000$.

(3) Hydraulic Press B. Co., \$4,443,000.

(4) Berghoff Brewing Corp., $\$ 4,764,000$.

(5) Automotive Steel P. Corp., $\$ 5,402,000$.

(6) Kalaniazoo Stove \& F. Co., $\$ 9,679,000$.

(7) Eastern Sugar Assoc., $\$ 11,142,000$.

(8) Aluminum Industries, Inc., $\$ 13,267,000$.

(9) Four Wheel Drive Auto Co., $\$ 18,002,000$.

(10) Jacobs Co., F. L., $\$ 20,402,000$.

(11) Phillip-Jones Corp., $\$ 24,673,000$.

(12) Cornell-Duhilier Electric Corp., $\$ 33,082,000$. 
Another useful common denominator of size which offers comparative possibilities on both a company and national basis is the number of employees of the various companies involved. ${ }^{33}$ The average number of individuals employed by the 21 of the 24 companies which were the subject of 1951 non-management proxy statements and for which employment data was available, and the same figure for the 20 of the 24 companies affected in 1952 (excludimg AT\&T's 551,415 employees) was 4,564 and 7,401, respectively. ${ }^{34}$ An estimated total of employees of the 48 companies affected

83 The nation's total civilian labor force employed in 1950 and 1951 was $63,099,000$ and 62,884,000 individuals, respectively (see THE Economac REPORT OF THE PRESIDENT AND THE Annual Econontc Review by the Council of Econontc Advisers (January 1953) 177.

34 Employment by 41 companies (excluding A.T.\&T.)

\begin{tabular}{|c|c|c|c|c|c|}
\hline Year & Average & $\begin{array}{c}\text { First } \\
\text { Quartile }\end{array}$ & Median & $\begin{array}{l}\text { Third } \\
\text { Quartile }\end{array}$ & $\begin{array}{l}\text { Mode or } \\
\text { Modal Class }\end{array}$ \\
\hline $\begin{array}{c}1950 \\
(21 \text { com- } \\
\text { panies }) \\
1951 \\
(20 \text { com- } \\
\text { panies }\end{array}$ & 4,564 & $\begin{array}{r}1,221 \\
788\end{array}$ & 2,193 & 4,900 & $162-1,571$ \\
\hline 1950 & $\begin{array}{l}\text { Hawarian } \\
\text { Pineapple } \\
\text { Co. }\end{array}$ & $\begin{array}{l}\text { Scullin } \\
\text { Steel Co. }\end{array}$ & $\begin{array}{l}\text { King- } \\
\text { Seeley } \\
\text { Corp. } \\
\text { Hudson } \\
\text { Manhattan } \\
\text { R.R. }\end{array}$ & $\begin{array}{l}\text { Hawaiian } \\
\text { Pineapple } \\
\text { Co. } \\
\text { United } \\
\text { Cigar. } \\
\text { Whelau } \\
\text { Stores }\end{array}$ & 6 companies \\
\hline 1951 & $\begin{array}{l}\text { Eastern } \\
\text { Sugar } \\
\text { Associates }\end{array}$ & $\begin{array}{l}\text { Automatic } \\
\text { Steel Prod. } \\
\text { Kalaniazoo } \\
\text { Stove, etc. }\end{array}$ & $\begin{array}{l}\text { Laclede } \\
\text { Gas Co. } \\
\text { Four Wheel } \\
\text { Drive } \\
\text { Auto Co. }\end{array}$ & $\begin{array}{l}\text { Eastern } \\
\text { Sugar } \\
\text { Assoc. } \\
\text { Cornell- } \\
\text { Dubilier } \\
\text { Elec. Co. }\end{array}$ & 12 companies \\
\hline
\end{tabular}

The lower portion of the above table substitutes the names of the companies, or in one column the number of companies, represented by employment figures shown in the table's upper portion. The six companies comprising the 1951 modal class, with number of persons employed, are:

1. American Bantam Car Co., 162.

2. Lawrence Portland Cement Co., 700.

3. Illinois Zimc Co., 840 .

4. United Board \& Carton Co., 1,000.

5. Scullin Steel Co, 1,100.

6. Hudson Manhattan R.R. Co., 1,342.

The 12 companies in the 1952 modal class with number of persons employed, are:

1. Securities Investment $\mathrm{Co}_{0}, 68$.

2. Jim Brown Stores, Inc., 186.

3. Berghoff Brewing Corp., 250.

4. Colonial Airlines, Inc., 524.

5. Hydrautic Press Brick Co., 650.

6. Automatic Stecl Products Co., 765.

7. Kalamazoo Stove \& F. Co., 810.

8. Aluuninum Industries, Inc., 1,350.

9. United Dye \& Carton Co., 1,370.

10. Four-Wheel Drive Auto Co., 2,000.

11. Laclede Gas Co., 2,165.

12. Jacobs, F. L., Co., 2,400 .

Of further comparative interest in connection with employment are the regulations of the Small Defense Plants Administration and the Department of Defense defining "sinall business," insofar as employment is concerned, in terms of 100 and 500 einployees, respectively. 
suggests strongly that, since non-management proxy statements were filed with respect to a total of only 109,536 employees or $.17 \%$ and 177,624 employees or $.28 \%$ of the $63,099,000$ and $62,884,000$ persons employed in 1950 and 1951, respectively, non-management solicitations under Regulation X-14 had no appreciable effect on the objective of full employment. ${ }^{35}$

\section{Industries in Which the Companies Operated}

During both 1951 and 1952, half of the companies involved in nonmanagement proxy solicitations under Regulation X-14 were manufacturing companies. ${ }^{36}$ However, in 1951, manufacturing assets were only $12 \%$

35 The estimated total of employees of the 241951 and 231952 companies was computed by taking the average for the 21 and 20 for which data was available, and multiplying the average by 24 . These estimated totals were then expressed as percentages of the nation's 1950 and 1951 total civilian force. For the latter figures, see supra note 33. The number of persons employed by the 12 and 11 manufacturing companies for which 1950 and $1951 \mathrm{em}-$ ployment data was available was:

\section{1}

1. American Bantam Car, 162.

2. Lawrence Portland Cement Co., 700.

3. Illimois Zinc Co., 840 .

4. United Board \& C. Corp., 1,000.

5. Scullin Steel Co., 1,100.

6. Aluminum Industries, Inc., 1,400 .

7. National Airlines, Inc., 1,900 .

8. Ainsworth Mfg. Co., 2,060.

9. King-Seeley Corp., 2,193.

10. Hawaiian Pineapple Co., Ltd, 4,800.

11. Houdaille Hershey Corp., 5,100.

12. Curtis Publishing Co., 7,300 .

\section{2}

1. Berghoff Brewing Corp., 250.

2. Hydraulic Press B. Co., 650.

3. Automatic Steel Products Co., 765.

4. Kalamazoo Stove \& F. Co., 810.

5. Aluminum Industries, Inc., 1,350 .

6. United Dye \& Chem. Corp., 1,370.

7. Four-Wheel Drive Auto Co., 2,000.

8. F. L. Jacobs Co., 2,400.

9. Phillips-Jones Co., 3,750.

10. Cornell-Dubillier Electric Corp., 5,600.

11. Eastern Sugar Associates, 7,500.

36 Number of companies by industry

\begin{tabular}{cccccccc} 
Year & Mfg. & R.R. & $\begin{array}{c}\text { Electric } \\
\text { Ry. \& Bus }\end{array}$ & Airline & $\begin{array}{c}\text { Trade, Finance } \\
\text { and Service }\end{array}$ & Utility & Total \\
\hline 1951 & 12 & 4 & 3 & 1 & 4 & 0 & 24 \\
$\%$ & $50 \%$ & $33.3 \%$ & $12.5 \%$ & $4.3 \%$ & $33.3 \%$ & 0 & $100 \%$ \\
1952 & 12 & 3 & 3 & 1 & 3 & 2 & 24 \\
$\%$ & $50 \%$ & $12.5 \%$ & $12.5 \%$ & $4.3 \%$ & $12.5 \%$ & $8.3 \%$ & $100 \%$ \\
\hline Total & 24 & 7 & 6 & 2 & 7 & 2 & 48 \\
$\%$ & $50 \%$ & $14.5 \%$ & $12.5 \%$ & $4.3 \%$ & $14.5 \%$ & $4.3 \%$ & $100 \%$ \\
\hline
\end{tabular}

The names of the manufacturing coinpanies, with their assets, will be found supra notes 24 and 25 . 
of the total assets of all 24 companies ${ }^{37}$ and the corresponding percentages for manufacturing assets of the 12 such companies affected in 1952 and the 1951-52 total were $4 \%$ and $7 \%$ excluding AT\&T the only company with assets of more than $\$ 1$ billion. ${ }^{38}$ Sales of the manufacturing companies were $57 \%$ and $15 \%$ of the 1951 and 1952 sales totals with $33 \%$ of the two year total representing sales of manufacturing companies, all figures again being exclusive of AT\&T. ${ }^{39}$

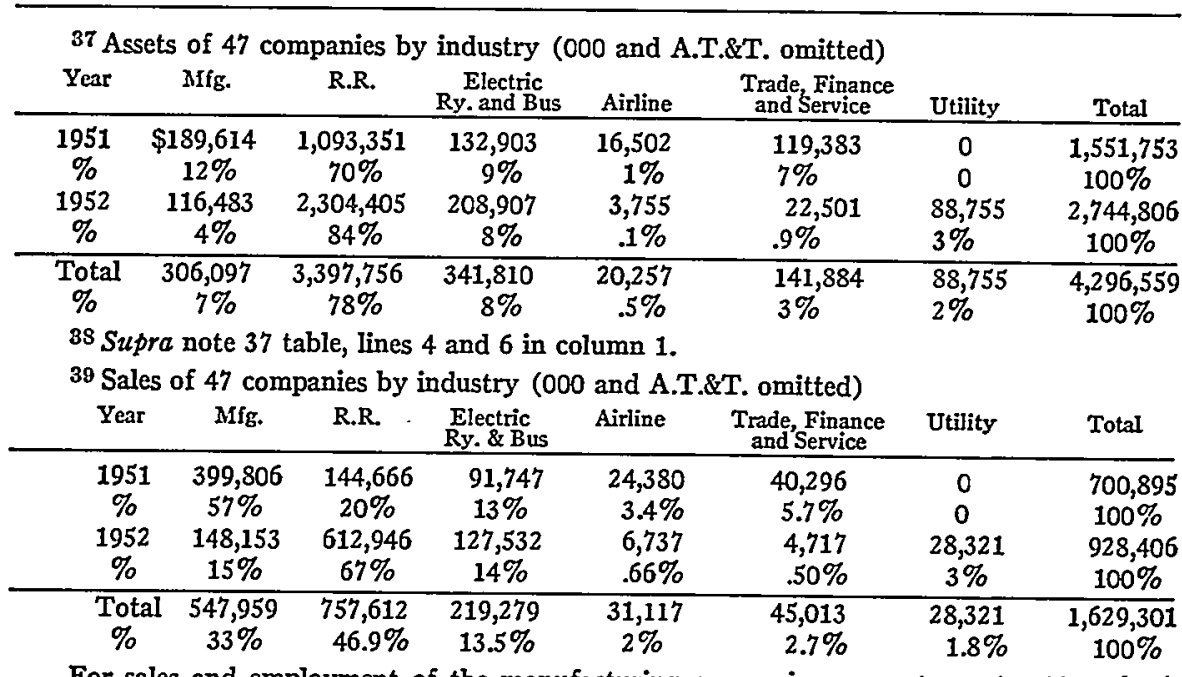

For sales and employment of the manufacturing companies, see supra notes 32 and 35 . The type of business done by the inanufacturing companies was:

1951

1. American Bantam Car Co., special equipment.

2. Lawrence Portland Cement Co., cement processer.

3. Illinois Zinc Co., mining and smelting.

4. United Board and C. Corp., paperboard producers.

5. Scullin Steel Co., steel castings.

6. Aluminum Industries, Inc., pistons.

7. Merchants Petroleum Co., oil royalties.

8. Ainsworth $\mathrm{Mfg}$. Co., auto equipment.

9. King-Seeley Corp., gauges.

10. Hawaïan Pineapple Co., growing, canning.

11. Houdaille Hershey Corp., auto accessories.

12. Curtis Publishmg Co., magazime publishing.

1952

1. Consolidated Royalty Oil Co., oil royalties.

2. Four-Wheel Drive Auto Co., heavy trucks.

3. United Dye \& Chein. Corp., dyes, chemicals.

4. Hydraulic Press B. Co., hydraulic presses.

5. Automatic Steel P. Corp., auto products.

6. Kalamazoo Stove \& F. Co., heating equipment.

7. Eastern Sugar Association, sugar producer.

8. Aluminum Industries, Inc., piston, auto parts.

9. Jacobs, F. L., \& Co., auto parts.

10. Phillips-Jones Corp., Van Heusen shirts.

11. Cornell-Dubilier Electric Corp., electric condensers.

12. Berghoff Brewing Corp., brewery. 
Transportation companies, namely, railroads, electric railway and bus companies, and airlines accounted for nearly one third of the companies involved in non-management proxy solicitations. ${ }^{40}$ For the two years, transportation companies' assets, however, constituted $86.5 \%$ of total assets, ${ }^{41}$ while their sales or revenue were about $62 \%$ of total sales. ${ }^{42}$ The balance of the industries was made up of trade, finance, and service companies, seven such compamies being included. ${ }^{43}$ In view of the frequency of depressed industries, such as railroads, electric railway and bus companies, and airlines, it is not surprising that among the 48 companies are three of the ten companies who have paid no dividends on their common stock since their listing on the New York Stock Exchange. ${ }^{44}$

\section{States of Incorporation and Cumulative Voting Rights}

While, as to be expected, Delaware leads as the most frequently recurring state of incorporation, there is quite a wide representation of states among the 48 companies. The 24 companies involved in the 1951 nonmanagement solicitations were incorporated in 12 different states and one

40 Supra note 36 , columns $2-4$, both inclusive. The companies were:

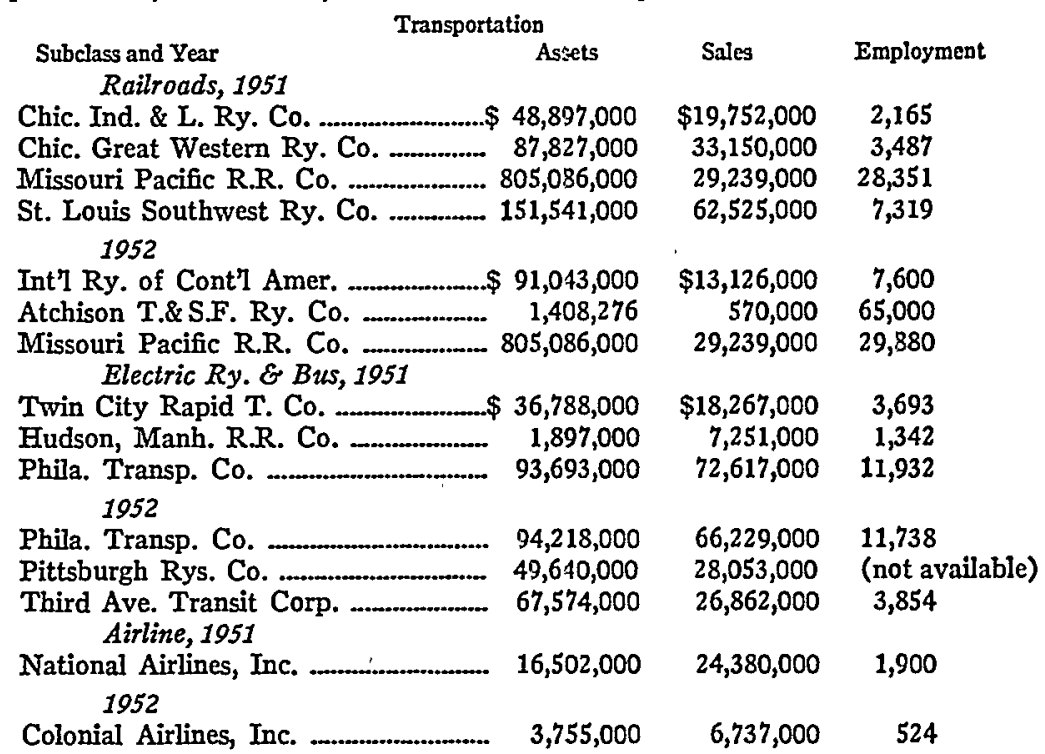

41 Supra note 37 , columns $2-4$, both inclusive.

43 Supra note 39 , columns $2-4$, both inclusive.

43 Supra notes 36,37 and 38 , columns 5 and 6.

44 The three companies referred to are Chicago Great Western Railway Company (sce Comment, Forcing Preferred Dividends: The Chicago Great Western Settlement, 19 U. OF CHr. L. REv. 878 (1952)), Third Avenue Transit Corp (see Note, A Reorganization Trustee's Power to Retake Creditor's Security for Use as Working Capital, 53 CoL. L. Rev. 273 (1953)), and International Railways of Central America, Wall Street Journal, April 30, 1953, p. 21, col. 3. 
in Hawaii, ${ }^{45}$ while the 24 companies which were the subject of 1952 solicitations were incorporated in 12 states. $^{46}$

Of the sixteen states and Hawaii in which the 48 companies imvolved in non-management proxy solicitations were incorporated, eight and Hawaii had mandatory provisions for cumulative voting, ${ }^{47}$ seven had permissive cumulative voting, ${ }^{48}$ and one had no requirement as to cumulative voting. ${ }^{49}$

\section{Number of Shareholders of Record and Type of Meeting Involved}

Figures were obtained as to the number of shareholders of record for 22 of the 24 companies involved in the 1951 non-management solicitations and for 23 of the 24 companies affected by the 1952 non-management solicitations. The average number of shareholders of record for the 221951 compamies and the 221952 companies (excluding AT\&T with 1,092,433 shareholders of record) was very close, 6,010 and 7,995 , respectively. ${ }^{50}$

The recent Brookings Institution survey showed men as owning of record $29 \%$ and women as owning of record $22 \%$ of the common stock of publicly held companies, and when joint personal holdings of record of $6 \%$ are added, individuals were estimated as owning of record $57 \% .^{51}$ Following the individual holdings of men and women and constituting the third largest

45 The states, with number of 1951 companies, are:
1. California, 1
5. Mllinois, 2
6. Indiana, 1
9. Missouri, 3
2. Delaware, 4
7. Michigan, 3
10. New Jersey, 1
13. Pennsylvania, 4
3. Florida, 1
8. Mimnesota, 1
11. New York, I
12. Ohio, 1

40 The states, with number of 1952 companies, are:
1. Delaware, 7
4. Maryland, 1
7. New Jersey, 1
10. Pennsylvania, 2
2. Indiana, 1
5. Michigan, 2
8. New York, 3
11. Wisconsin, 1
3. Kansas, 1
6. Missouri, 3
9. Ohio, I
12. Wyoming, 1

47 The eight states with mandatory cumulative voting were Calif., Ml., Kans., Mich., Mo., Ohio, Pa., and Wyo.

48 The seven states with permissive cumulative voting were Del., Fla., Ind., Md., Minn., N.J., and N.Y.

49 The state having no provision for cumulative voting was Wisconsin.

50 Sharcholders of record for the 44 companies, with A.T.\&T. excluded from the 1952 average and modal class, were:

\begin{tabular}{|c|c|c|c|c|c|}
\hline Year & Average & $\begin{array}{c}\text { First } \\
\text { Quartile }\end{array}$ & Median & $\begin{array}{l}\text { Third } \\
\text { Quartile }\end{array}$ & $\begin{array}{l}\text { Mode or } \\
\text { Modal Class }\end{array}$ \\
\hline 1951 & 6,010 & 820 & 1,912 & 6,169 & $272-2,583$ \\
\hline 1952 & 7,995 & 1,009 & 1,868 & 10,193 & $238-3,212$ \\
\hline 1951 & $\begin{array}{l}\text { Hawailian } \\
\text { Pme. Co. }\end{array}$ & ㅍll. $\mathrm{Zmc}$ & $\begin{array}{l}\text { King-Seeley } \\
\text { Twin City R. }\end{array}$ & Mo. Pac. R.R. & 13 companies \\
\hline 1952 & $\begin{array}{l}\text { Mo. Pac. } \\
\text { R.R. }\end{array}$ & $\begin{array}{l}\text { Hydraulic } \\
\text { P. Brick }\end{array}$ & $\begin{array}{l}\text { Berghoff Brew- } \\
\text { ing Corp. } \\
\text { Eastern } \\
\text { Sugar }\end{array}$ & Mo. Pac. R.R. & 16 coinpanies \\
\hline
\end{tabular}

The lower portion of the above table substitutes the name or number of companies represented by the shareholder-of-record figure in the upper portion of the table.

51 KIMMEx, Share OWNershIP IN THE UNITEd States 15 (1952). Cf. Crum, Analysis of Stock Ownership, 31 Harv. Bus. Rev. 36 (1953), and A Proposal to American Business, id. at 33 . 
type of holder of record was the "others" or miscellaneous classification with over 471 million shares, whose high standing, amounting to about $13 \%$, was attributed to the large holdings of insurance companies and investnient companies. ${ }^{52}$ In view of legal limitations imposed by state statutes on investment in common stocks by insurance conipanies and the nearly $300 \%$ increase in total assets of investment conpanies from approximately $\$ 21 / 2$ billion as of June $30,1941^{53}$ to over $\$ 71 / 4$ billion as of December 31 , $1952,{ }^{54}$ it seems worthwhile to consider to what extent investment contpanies through their holdings of record in the 48 companies involved in non-managentent proxy solicitations under Regulation X-14 were in a position to affect the results by their voting position.

The assets of the 19 largest nanagement open-end companies amounted to $\$ 2,848$ million and the assets of the 13 largest management closed-end conpanies to $\$ 2,765$ million or a total of $\$ 5,613$ million as of December 31, $1952 .{ }^{54}$ Inasmuch as total assets at the indicated date of all investment conipanies were $\$ 7,274$ inillion, ${ }^{55}$ the $\$ 5,613$ million total for the 19 largest open-end and the 13 largest closed-end companies accounted for $77 \%$ of total assets of investment companies. Consequently, the holdings of the 19 and 13 largest open and closed-end companies would appear to afford considerable insight into the position of investment companies generally of record in the 48 companies involved in the 1951 and 1952 non-management proxy statements.

Holdings of only mine of the 48 companies showed up in the portfolios of the 19 and 13 largest open and closed-end companies, and in only two instances were their holdings more than $4 \%$ of the shares outstanding. ${ }^{50}$ Of these two, nearly $5 \%$ of Chicago Great Western preferred was held by National Securities Series and 5 to $10 \%$ of National Airlines was owned

$52 I d$. at 16 . The remaining $30 \%$ was found to be held by (1) fiduciaries, $7 \%$; (2) institutions and foundations, $1.8 \%$; (3) brokers and dealers, $11 \%$; and (4) nominees, $9.8 \%$.

53 SEC 7th ANN. REP. 9 (1941).

54 The source of the figures given is a letter dated June 8,1953 , received from Mr. Charles R. McCutcheon, an Assistant Director of the SEC's Division of Trading and Exchanges.

55 Ibid.

56

$\quad \begin{gathered}\text { Name of } \\ \text { Company }\end{gathered}$
1. Chicago Great W.
2. Curtis Pub. Co.
3. United Cigar W.
4. National Airlines
5. RKO Theatres
6. Laclede Gas
7. A.T.\&T.
8. Atchison T. \& S.F.
9. Kalamazoo S. \& F.

32 Investment Coinpany Holdings

\begin{tabular}{rrrc}
\multicolumn{2}{c}{$\begin{array}{c}\text { Investment } \\
\text { Shares }\end{array}$} & $\begin{array}{c}\text { Companies' } \\
\text { No of Investment } \\
\text { Number of } \\
\text { Shandings }\end{array}$ & $\begin{array}{c}\text { \% of Out- } \\
\text { Company Holders } \\
\text { Standing Held }\end{array}$ \\
366,104 & 1 & 17,000 & 4.643 \\
$4,147,194$ & 2 & 24,200 & 0.583 \\
$2,307,220$ & 1 & 38,000 & 1.647 \\
$1,000,000$ & 2 & 103,500 & 10.003 \\
$3,914,913$ & 1 & 10,000 & 0.255 \\
$3,031,385$ & 1 & 30,000 & 0.989 \\
$33,651,918$ & 5 & 53,900 & 0.160 \\
$7,337,576$ & 15 & 226,000 & 3.080 \\
300,000 & 1 & 300 & 0.100
\end{tabular}


by Investors Mutual, Inc. Except, therefore, for Investors Mutual, Inc.'s 5 to $10 \%$ ownership of National Airlines, it would appear that investment companies did not hold a substantial voting position. ${ }^{57}$ Nevertheless, they were in a position by virtue of their holdings to provide informed shareholder leadership or comment, but apparently did not avail themselves of their opportumities in any instance.

Not all of the non-management filings were directed at shareholders meetings, some having been prepared with a view to the solicitation merely of consents to class representation. However, im 1951, annual meetings were involved in 12 instances and special meetings in 7, while in 1952, annual meetings numbered 18 and special meetings 2. In several instances the special meetings were at the call of the management, ${ }^{68}$ but in others they were sought by the non-management solicitors. ${ }^{69}$ The elaborate preparations generally taken by management in connection with its solicitation of proxies for annual meetings ${ }^{60}$ and the resultant organized opposition that therefore may be expected to be encountered by a non-management group affords practical grounds for non-management groups undertaking to solicit in respect to a demanded special rather than an annual meeting.

\section{SURVEY SOLICITATION DATA}

Consideration having been given in summary fashion to the background in which the 1951 and 1952 non-management solicitations under

D7 It is also to be noted that in order to be a "diversified company" a registered management open or closed-end company must under the Investment Company Act of 1940, inter alia, limit its holdings "in respect of any one issue to an amount not greater in value than 5 per centum of the value of the total assets of such management company and to not more than 10 per centum of the outstanding voting securities of such issuer." 15 U.S.C. $\$ 80 a-5$ (b) (1) (1947). See also 15 U.S.C. $\$ 80 a-5$ (c) (1947).

68 Special meetings at the call of management involved the following compames for the indicated dates and purposes:

1. Selected Industries, Inc.

2. Sovereign Investors, Inc.

3. Merchants Petroleum Co.

4. Lawrence Portland Cement Co.

5. United Dye \& Chem. Corp.
March 8, 1951

May 14, 1951

May 31, 1951

October 16, 1951

July 31,1952
Merger

Replace directors

Elect directors

Merger and cumu-

lative voting

Increase authorized common stock

50 Special meetings at the call of non-management solicitors were proposed with respect to the following companies for the indicated dates and purposes:
1. United Board and C. Corp.
Undetermined
Increase number
2. United Cigar W. Stores
September 25, 1951
of directors
3. Phila. Transportation Co.
December 10, 1951
Remove and re- place directors
4. Kalamazoo Stove \& F. Co.
May 16, 1952
By-law amendments Remove and re- place directors

60 See Caplin, Proxies, Annual Meetings and Corporate Democracy: The Lavoyer's Role, 37 VA. L. REv. 653, 658-663 (1951); Prentice-Hall Securities Regulation Service II 13,092; Prentice-Hall Corporation Letter (Nov. 1951). 
Regulation X-14 took place, attention may now be focused on the more significant aspects of the non-management solicitations themselves and the non-management soliciting groups. Among the matters to be examined are the security holdings of the non-management solicitors, their occupations, their soliciting material, the objectives they sought to accomplish, whether personal as well as mail solicitation was carried on, data bearing on solicitation expenses, and the results of the voting by the shareholders. Also, several of the non-management solicitations will be briefly reviewed on a case study basis. In addition, comments furnished by the management and non-management groups will be summarized. From this aggregate of data conclusions with respect to Regulation X-14's prospects for promoting shareholder democracy and inspired corporate leadership will then be suggested.

\section{Security Holdings and Occupations}

Security holdings were obtained for the non-management soliciting groups for 23 and 22, respectively, of the 48 companies involved in 1951 and 1952 non-management solicitations. ${ }^{01}$ Almost invariably the security holdings of each group were small, amounting on the average, to but $7 \%$ in 1951 and $7.8 \%$ in $1952 .{ }^{\circ 2}$

Six occupations accounted for $81.7 \%$ of the non-mauagement nominees for directorships or security holders' committee members, 181 such individuals being tabulated for 40 of the 48 companies affected. ${ }^{63}$ Over a third or $38.6 \%$ were business men, while $15.4 \%$ were attorneys, $12.7 \%$ securities broker-dealers, $5.5 \%$ each engineers and accountants, and $7 \%$ private investors. The remainder were divided among 13 occupational classifica-

61 Regulation X-14, in its Schedule 14A, Item 6(c) (3) requires that the proxy statement set forth the approximate amount of each class of securities of the issuer, its parents, or its subsidiaries beneficially owned directly or indirectly by nominees for directorships. See also Items $6(\mathrm{c})(4)$ and 5 regarding security holdings. Substantial interests in any inatter to be acted upon of persons in whose behalf solicitation is undertaken, of nominees, and of their associates are required by Items 4 (b)-(d) also to be stated in the proxy statement.

62 Security. Holding of Non-Management Soliciting Groups (A.T.\&T. omitted)

$\begin{array}{llllcc}\text { Year } & \text { Average } & \begin{array}{c}\text { First } \\ \text { Quartile }\end{array} & \text { Median } & \begin{array}{c}\text { Third } \\ \text { Quartile }\end{array} & \begin{array}{c}\text { Mode or } \\ \text { Modal Class }\end{array} \\ 1951 & 7 \% & 1.3 \% & 4.0 \% & 8 \% & 4 \% \& 8 \% \\ 1952 & 7.8 \% & 0.3 \% & 2.4 \% & 8 \% & 0.3 \% \\ 1951 & \text { RKO } & \text { Houdaille } & \text { Chic. Ind. } & \text { King- } & 4 \text { cos. } \\ & \text { Tlieatres } & \text { Hershey } & \text { R.R. } & \text { Seeley } & \text { each } \\ 1952 & \text { Laclede } & \text { Hydraulic } & \text { Berghoff } & \text { Laclede } & 4 \text { cos. } \\ & \text { Gas } & \text { Press Co. } & \text { Brewing } & \text { Gas } & \end{array}$

The lower portion of the above table substitutes the name or number of companies represented by the figure shown in its upper portion.

63 Occupation and experience data are required by Item $6(c)(1)$ and (d). 
tions. ${ }^{64}$ Inasmuch as most of the business men involved were business executives, it is apparent that few among the 181 individuals were ordinary salaried or wage employees, and that almost all were experienced executive or professional persons in a position by virtue of the type of their employment to devote a considerable portion of their time to solicitation for the period during which proxy solicitation would need to be carried on.

\section{Volume and Timing of Soliciting Material}

On the average the non-management soliciting groups employed approximately two mailings, nainely, an opening letter and/or proxy statement and one follow-up mailing, the two averaging in all about seven pages in length. In eleven instances, however, non-management groups employed four or more mailings averaging a total of 14 pages. $^{65}$

The average and median time between the non-management groups' first mailing and the annual or special meeting to which the solicitation was directed was 25 and 20 days, respectively, for 39 of the 48 solicitations involving annual or special meetings. While the elapsed time ranged from as low as $\operatorname{six}^{66}$ to as high as 114 days, ${ }^{67}$ it would seem that in general it would have been desirable for the non-management groups to have dis-

64 The balance of the 181 individuals were engaged in the numbers indicated in the occupations shown:
1. Financial Consultant, 6
8. Hoineinaker, 2
2. Banker, 5
3. Educator, 4
9. Druggist, 1
4. Insurance broker, 4
5. Physician, 2
10. Public Official, 1
6. Agriculturalist, 2
11. Investment Co. exec., I
12. Public Relations, 1
13. Labor Union, 1
7. Management Consultant, 2

65 The eleven non-inanagement solicitations in which four or more mailings were used grouped by name of company, number of mailings and number of pages, respectively, were:
1. Twin City R. Tr. Co., 7, 28pp.
7. Chic. Grt. W., 4, 3pp.
2. United Cigar W., 5, 16pp.
3. National Airlines, 6, 22pp.
8. Colonial Airlines, 4, 11pp.
4. King-Seeley, 4, 11pp.
5. Phila. Tr. Co., 4, 7pp.
9. Consol. Royalty Oil, 4, 6pp.
10. Aluminum Indus., $4,8 \mathrm{pp}$.
11. Jacobs, F. L., \& Co., 6, 19pp.
6. RKO Theatres, 5, 23pp.

Under X-14's Rule X-14A-6(a) three prehiminary copies of the proxy statement and form of proxy and any other soliciting material to be furnished to security holders concurrently with the proxy and proxy statement inust be filed with the SEC at least 10 days prior to the date definitive copies are first sent or given to security holders, or such shorter period prior to that date as the SEC may authorize upon a showing of good cause. Definitive copies of the proxy, proxy statement, and concurrently furnished inaterial inust under X-14A-6(c) be filed with or mailed to the SEC not later than the date it is first sent or given to security holders.

Three preiminary copies of any "additional" or follow-up soliciting material must under $\mathrm{X}-14 \mathrm{~A}-6$ (b) be filed with the SEC at least two days (exclusive or Saturdays, Sundays, or hohdays) prior to the date it is first sent or given to security holders, or such shorter period prior to that date as the SEC may authorize upon a showing of good cause. See also X-14A-6(d)-(f) and note.

66 See 1951 first non-management proxy mailing relating to Chicago, Indianapolis \& Louisville Ry. Co. and to Four Wheel Drive Auto Co.

67 See 1952 first non-management proxy mailing relating to F. L. Jacobs Co. 
patched their first mailing earlier and therefore to have filed and cleared their proxy statements with SEC earlier.

\section{Objectives: Proposal Subjects and Directorship Issues}

In terms of objectives, non-management solicitations may be divided into two classes; (1) those conducted in support of proposals for corporate action, and (2) those aimed at electing nominees to directorships. Each of these may be further divided into two subclasses. Proposals are usually either (1) specific in that particular action is urged, or (2) general in that through consents, representation of a class of security holders is sought. Directorships, too, are ordinarily desired either for (1) the specific purpose of obtaining inerely minority representation for a particular goup of security holders, or (2) the more general purpose of securing a majority of the directorships and thus obtaining actual control of the corporation. In some instances both proposals and directorships were objectives of the nonmanagement solicitation..$^{88}$ By way of summary, for the two years 1951 and 1952 , one or more directors were sought to be elected in $3 / 4$ of the nonmanagement solicitations, in half of them proposals were employed, and in about $1 / 4$ both directorships and proposals were involved.

\section{Proposal Subjects}

Of the 24 instances of X-14 non-management solicitations in 1951 and 1952 in support of proposals, 19 or nearly $80 \%$ involved proposals for specific corporate action rather than consents for class representation. Moreover, only one proposal solicitation in 1952 was directed to class representation. ${ }^{69}$ The proposals for corporate action concerned a variety of matters, namely, increasing or decreasing board of directors, ${ }^{70}$ removal and replacement of all directors, ${ }^{71}$ audit, ${ }^{72}$ merger or sale of assets, ${ }^{73}$ pen-

68 Both directorships and proposals were involved in the non-management solicitations relating to the following 11 companies: In 1951, Chicago, Indianapolis \& Louisville R.R. Co., Twin City Rapid Transit Co., Ainsworth Mfg. Co., Curtis Publishing Co., Scullin Steel Co., Hawaiian Pineapple Co., United Cigar Whelan Stores Co., National Airlines, Inc.; in 1952, Colonial Airlines, Inc., Kalamazoo Stove \& Furnace Co., and Jim Brown Stores, Inc. In only one such instance, Hawaiian Pineapple $\mathrm{Co}$., where minority directorship representation was sought, did the non-managennent group avail itself of the privilege afforded by X-14A-8 of obligating management to include the non-management proposals in the management proxy statement. As to X-14A-8, see infra pp. 420-21 and supra pp. 395-96.

69 The one 1952 non-management solicitation seeking class representation was in respect of Third Avenue Transit Corp. The four companies who in 1951 experienced such non-management sohititations were: American Bantam Car Co., Chicago, Indianapolis \& Louisville Ry. Co., Chicago Great Western R.R. Co., and Hudson Manhattan Ry. Co.

70 Increase: United Board \& Carton Co. (1951); Decrease: Curtis Publishing Co. (1951).

71 Twin City Rapid Transit Co. (1951), United Cigar Whelan Stores Co. (1951), and Kalamazoo Stove \& Furnace Co. (1952).

72 Twim City Rapid Transit Co. (1951) and United Cigar Whelan Stores Co. (1951).

73 Against merger: Selected Industries, Inc. (1951) and Lawrence Portland Cement Co. (1951) ; for merger or sale: Jin Brown Stores, Inc. (1952) and Kalaunazoo Stove \& Furnace Co. (1952); and against merger with Eastern Airlines, Inc., and for merger with Colonial Airlines, Inc.: National Airlines, Inc. (1951). 
sion plans, ${ }^{74}$ dividends to be paid quarterly instead of annually or to be paid in larger ainounts, ${ }^{75}$ executive stock purchases and einployment contracts, ${ }^{76}$ against elimination of curnulative voting, ${ }^{77}$ by-law amendments, ${ }^{78}$ and issuance or distribution of stock. ${ }^{79}$ In only three instances, surprisingly, was the X-14A-8 proposal rule utilized to support proposals which were the subject of non-management proxy statements. ${ }^{80}$

\section{Directorship Issues and Proposal Subjects}

Of the $31 \mathrm{X}-14$ non-management solicitations in 1951 and 1952 in support of the election of non-inanagement nominees to directorships, slightly less than half, or 12, were merely for the purpose of securing minority representation on the board of directors and therefore did not involve a contest for corporate control. In 1951 there were five, representing nearly $21 \%$ of the non-management solicitations in that year. ${ }^{81}$ For 1952 there was an increase to seven, representing nearly $1 / 3$ of the non-management solicitations for the indicated year. ${ }^{82}$ During 1951 there were nine contests, amounting to $37.5 \%$ of the non-management filings, seeking a majority of the directorships and therefore control of the corporation. ${ }^{83}$ For 1952 there was an increase of but one, bringing to ten the number of contests for control, constituting about $42 \%$ of the non-management filings for that year. ${ }^{84}$

In an effort to ascertain what were the security holder's points of

74 Pension plan for "salaried" employees only: Ainsworth Mfg. Co. (1951) and pension plan for all organized employees: A.T.\&T. Co. (1952).

70 Dividends quarterly instead of annually: Scullin Steel Co. (1951) and larger dividends: Atchison, Topeka \& S. Fe R.R. Co. (1952).

To Executive stock purchases: Hawaüan Pimeapple Co. (1951) and executive employment contracts: Phillips-Jones Corp. (1952).

77 National Airlines, Inc. (1951) and Lawrence Portland Cement Co. (1951).

78 National Airlines, Inc. (1951) and Philadelphia Transportation Co. (1951).

79 Issuance of additional stock: National Airlines, Inc. (1951) and United Dye \& Chemical Co. (1952); distribute stock, Atchison, Topeka \& S. Fe R.R. Co. (1952); and exchange of stock, Eastern Sugar Associates (1952).

80 Hawaïan Pineapple Co. (1951), A.T.\&T. Co. (1952) and Atchison, Topeka \& S. Fe R.R. Co. (1952). Cf. infra pp. 420-21 and supra pp. 395-96.

81 The five 1951 non-inanagement solicitations for a minority of directors involved: Cbicago, Indianapolis \& Louisville Ry. Co., Curtis Publishing Co., St. Louis Southwestern Ry. Co., Hawä̈an Pineapple $\mathrm{Co}$, and National Airlines, Inc.

82 The seven 1952 non-manageinent solicitations for a minority of directors involved: Laclede Gas Co., Cornell-Dubilier Electric Co., Hydraulic Press Brick Co., Philadelphia Transportation Co., Pittsburgh Rys. Co., Automatic Steel Products Co., and Four Wheel Drive Auto Co.

83 The nine 1951 contests for control related to: Twin City Rapid Transit Co., Ainsworth Mfg. Co., Scullin Steel Co., Missouri Pacific R.R. Co., Merchants-Petroleum Co., United Cigar Whelan Stores Co., King-Seeley Corp., RKO Theatres Corporation, and Illinois Zinc Co.

84 The ten 1952 contests for control concerned: International Railways of Central America, Inc., Colonial Airlines, Inc., Missouri Pacific R.R. Co., Securities Investunent Co., British Type Investors, Inc., Kalamazoo Stove \& Furnace Co., F. L. Jacobs Co., Consohidated Royalty Oil Co., Aluminum Industries, Inc., and Berghof Brewing Corp. 
contention, all the proxy soliciting material filed with the SEC by nonmanagement groups in connection with 1951 and 1952 non-management solicitations were examined. The survey showed that a total of 163 issues or subjects were presented in support of the various solicitations in behalf of proposals and/or for directorships. As will be seen, in general the issues and subjects involved related largely to complaints of poor management or mismanagement by directors and management officials and low or no dividends. This contrasts sharply with the subject matter of proposals submitted under Rule X-14A-8, in the four year period 1948 through 1951, which were concerned principally with cumulative voting and the stagger system, post-meeting reports and meeting places, and selection of auditors. ${ }^{85}$

Issues and subjects relating to directors led numerically with 30 or approximately $18 \%$ of the 163 contentions observed; those relating to management officials accounted for another 23 or about $14 \%$. As a result nearly $1 / 3$ of the complaints charged dealt with either poor management or nnismanagement by directors or management officials. Dissatisfaction with directors was expressed in a variety of manners, the most common, noted in seven instances, being small stock ownership of directors. ${ }^{80} \mathrm{Sec}-$ ond most common directorship issue was the desire in five contests for outside or independent directors. ${ }^{87}$ Third in point of frequency was the presence in four instances of the closely allied demand for a director to represent stockholders rather than management.$^{88}$ Other issues or subjects relating specifically to directors concerned removal of all directors, ${ }^{80}$ conduct of the person who was a director and the president of the company, ${ }^{00}$ conflicting positions, ${ }^{91}$ increase or decrease in number of directors, ${ }^{02}$ directors powers to amend by-laws, ${ }^{03}$ and director committee powers. ${ }^{04}$

\footnotetext{
85 See infra note 172 and supra note 10.

80 Small stock ownership of directors was an issue in respect of the following companies: 1952 ; Ainsworth Mfg. Co., Scullin Steel Co., R.K.O. Theatres Corp., and Illinois Zinc Co.; 1952; Cornell-Dubilier Electric Co., International Ry. of Central America, and Philadelphia Transportation Co.

${ }^{87}$ Outside or independent directors was contended for at the following: King-Seeley Corp. (1951), and Hydraulic Press Brick Co., Four Wheel Drive Auto Co., Aluminum Industries, Inc., and F. L. Jacobs Co. (1952).

88 Curtis Publishing Co. (1951), RKO Theatres Corp. (1951), Laclede Gas Co. (1952), and F. L. Jacobs Co. (1952).

80 Twin City Rapid Transit Co. (1951), United Cigar Whelan Stores Co. (1951), and Kalamazoo Stove \& Furnace Co. (1952).

${ }^{90}$ Ainsworth Mfg. Co. (1951), National Airlines, Inc. (1951), and Consolidated Royalty Oil Co. (1952).

91 Chicago, Indianapolis \& Louisville Ry. Co. (1951) and Philadelphia Transportation Co. (1952).

92 Increase: United Board \& Carton Co. (1951) and United Dye \& Clemical Co. (1952); decrease: Curtis Publishing Co. (1951) and Lawrence Portland Cement Co. (1951).

${ }^{93}$ National Airlines, Inc. (1951).

94 Philadelphia Transportation Co. (1951).
} 
Management in particular, rather than directors, was an issue in 23 instances, accounting for $14 \%$ of all issues proffered and ranked third numerically. Of a wide range of management type objections, the most common was poor management or mismanagement. ${ }^{95}$ Other lapses charged against management included lack of company growth and diversification, ${ }^{96}$ advertising policy, ${ }^{97}$ personnel and training programs, ${ }^{98}$ buying, expenses, and the war effort, ${ }^{99}$ merchandising and pricing. ${ }^{100}$ Still others were failure to meet competition, ${ }^{101}$ absentee management, ${ }^{102}$ loans, ${ }^{103}$ and management by parents and management of subsidiaries. ${ }^{104}$

Low or no dividends or earmings, the second most frequent complaint, tallied 26 or $15 \%$ of the issues and subjects projected. ${ }^{105}$ In 15 or $9 \%$, remuneration was an issue. Executive remuneration generally was assailed, ${ }^{106}$ and there were also more specific remuneration objections relating to pension, retirement, employment, and bonus contracts. ${ }^{10 \pi}$ Again, in 13 or $8 \%$, merger or other acquisition was an issue; ${ }^{108}$ in six or nearly $4 \%$, cumulative voting or the stagger system was debated. ${ }^{109}$

85 United Cigar Whelan Stores Corp. (1951), International Railways of Central America, British Type Investors, Inc. (1952), Kalamazoo Stove \& Furnace Co. (1952), and F. L. Jacobs Co. (1952).

96 King-Seeley Corp. (1951), Consolidated Royalty Oil Co. (1952), and F. L. Jacobs Co. (1952).

97 Curtis Publishing Co. (1951), United Cigar Whelan Ctores Corp. (1951), and KingSeeley Corp. (1951).

98 United Cigar Whelan Stores Corp. (1951) and F. L. Jacobs Co. (1952).

99 Ibid.

100 Ibid.

101 RKO Theatres Corp. (1951).

102 Ibid.

103 Four Wheel Drive Auto Co. (1952) and F. L. Jacobs Co. (1952).

104 International Railway of Central America (1952) and F. L. Jacobs Co. (1952).

105 Ainsworth Mfg. Co. (1951), Curtis Publishing Co. (1951), Scullin Steel Co. (1951), United Cigar Whelan Stores Co. (1951), King-Seeley Corp. (1951), RKO Theatres Corp. (1951), Laclede Gas Co. (1952), Cornell-Dubilier Electric Co. (1952), International Railways of Central America (1952), Hydraulic Press Brick Co. (1952), Atchison, Tokeka \& Santa Fe R.R. Co. (1952), Philadelphia Transportation Co. (1952), British Type Investors, Inc. (1952), F. L. Jacobs Co. (1952), Consolidated Royalty Oil Co. (1952), Four Wheel Drive Auto Co. (1952), Aluminum Industries, Inc. (1952), and Berghoff Brewing Corp. (1952).

100 National Airlines, Inc. (1951), Cornell-Dubilier Electric Corp. (1952), British Type Investors, Inc. (1952), F. L. Jacobs Co. (1952), Four Wheel Drive Auto Co. (1952), and Aluminum Industries, Inc. (1952), Illinois Zinc Co. (1951), and Berghoff Brewing Corp. (1952). 107 Ainsworth Mfg. Co. (1951), National Airlines, Inc. (1951), A.T.\&'T. (1952), PhillipsJones Corp. (1952), and F. L. Jacobs Co. (1952).

108 Selected Industries, Inc. (1951), Ainsworth Mfg. Co. (1951), Lawrence Portland Cement Co. (1951), Colonial Airlines, Inc. (1952), Securities Investment Co. (1952), Kalamazoo Stove \& Furnace Co. (1952), Jim Brown Stores Co. (1952), and United Dye \& Chemical Corp. (1952).

109 Curtis Publishing Co. (1951), National Airlines, Inc. (1951), Lawrence Portland Cement Co. (1951), Laclede Gas Co. (1952), British Type Investors, Inc. (1952), and Four Wheel Drive Auto Co. (1952). 


\section{Personal Solicitation and Solicitation Expenses}

In virtually every instance some non-management personal, in addition to mail, solicitation was carried on. Moreover, in 1951, seven, and in 1952, five, of the non-management groups employed paid proxy soliciting firms, as management frequently does, to supplement their own personal solicitation. ${ }^{110}$

Incomplete non-management expense data was obtained under promise of confidential treatment as to identity with respect to 15 of the 24 companies involved in 1951 non-management solicitations. Expenses of nonmanagement groups in 1951 ranged from $\$ 50$ to in two instances $\$ 30,000$, with an average and median for the 15 of $\$ 7,077$ and $\$ 8,750$, respectively. Similarly, in 1952 non-management expenses in connection with 16 of the 24 companies ranged from $\$ 200$ to $\$ 55,841$, with an average and median of $\$ 10,652$ and $\$ 2,225$, respectively. ${ }^{111}$

\section{Results of Voting by Security Holders}

For the instances in which the number of shares voted were obtained, shares voted as a percentage of shares outstanding was far in excess of the percentage of citizens voting in national political elections, a consequence no doubt of the intensive personal proxy solicitation ordinarily carried on at least by management. Over $82 \%$ of the shares outstanding were voted, according to figures secured for nine of the 24 companies involved in 1951 non-management filings, while in 1952 the percentage voted in respect of 16 of the 24 companies was $85 \%$.

Results of voting to be meaningful must be considered from the standpoint of the non-management groups' objectives. Consequently, attention will be given to the two primary types of non-management solicitations, those relating to directorships and those relating to proposals, with individual provision for the secondary types, consisting of directorship solicitations for control and for representation, and proposal solicitations for corporate action and for consents to class representation. ${ }^{112}$

Data as to results was obtained for 10 of the 11 companies which in 1951 were mvolved in non-management solicitations in support of proposals for corporate action. They showed only two proposals drawing more than $50 \%$ of the shares voted. One was a proposal for the removal and

110 Non-management groups employed paid proxy soliciting firms in respect of the following 12 of the 48 compames. In 1951: Twin City Rapid Transit Co., Ainsworth Mfg. Co., Curtis Publishing Co., United Cigar Whelan Stores Corp., National Airlines, Inc., King-Secley Corp., and RKO Theatres Corp. In 1952: Colomial Airlines, Inc., British Type Investors, Inc., Consolidated Royalty Oil Co., Aluminum Industries, Inc., and F. L. Jacobs Co.

111 As to proxy contest expenses, see infra, note 14 .

112 See supra pp. 414-417. 
replacement of directors; ${ }^{113}$ the other for an audit of financial affairs. ${ }^{114}$ The median percentage of votes cast for proposals directed to the ten companies was 28\%. Proposal results for six of eight companies in 1952 showed that, in another instance where proposals to remove and replace directors were coupled with proposals to sell equipnent and reject a nerger plan, the merger was rejected by a $56 \%$ vote..$^{115}$ None of the $1952^{\circ}$ proposals, except the unopposed Jim Brown Stores, Inc. non-management proposal for merger, drew more than a $50 \%$ favorable vote. ${ }^{116}$ The median percentage of votes cast for proposals directed to six of the eight 1952 companies was $37 \% .^{117}$ No results were obtained for any of the four 1951 or for the one 1952 solicitation of consents to class representation. ${ }^{118}$

A measure of the success of a non-management solicitation for less than a majority of directorships is afforded by comparison of the number of directorships sought with the number of directorships obtained. In four 1951 minority representation contests non-management groups elected six, or half, of the nommees presented to security holders. ${ }^{119}$ In seven 1952 minority representation contests non-management groups elected only five of 17 , or $29 \%$ of their nominees, in three instances not electing a single director. ${ }^{120}$

113 Twin City Rapid Transit Co. (1951) and United Cigar Whelan Stores Corp. (1951). The availability of the removal technique is dependent upon state law and/or charter provisions. For a discussion of the matter, including omission of provision for directors' removal from the American Bar Association's "Model Corporation Act," see What's. New in Corporation Laws, 8 The Business Lawyer 27-32 (January 1953).

114 Twin City Rapid Transit Co. (1951), and United Cigar Whelan Stores Corp. (1951).

116 Kalamazoo Stove \& Furnace Co. (1952). A two-thirds favorable vote was required to make the merger effective.

110 Shortly after the Jim Brown Stores management had mailed its proxy statement for its 1952 annual meeting, to have been held for the purpose of electing management's slate of directors, a merger agreement was negotiated with Bearing Specialists, Inc. and arrangements made for sale of management's and subsequently other sharebolder's Jin Brown stock to the Bearing Specialists management group. In connection with their offer to buy non-management Jim Brown shares, the Bearing Specialists group also solicited non-management Jim Brown proxies in favor of the proposed merger. In the interval the Jim Brown annual meeting was adjourned, the Jim Brown managenent having refrained in deference to $\mathrm{X}-14 \mathrm{~A}-4$ (d) and (e) from voting its proxies.

117 One proposal against executive enployment and retirement contracts was withdrawn due to cancellation of the proposed contracts. See Phillips-Jones Corp. (1952).

118 See supra p. 414.

119 Curtis Publishing Co. (1951)-nominated 3, elected 1; St. Louis Soutbwestern Ry. (1951)-nominated 1, elected 1; Hawaïan Pimeapple Co. (1951)-nominated 3, elected 1; and National Airlines, Inc. (1951)-nominated 5, elected 3. The Chicago, Indianapolis \& Louisville Ry. Co. (1951) filing involved an unsuccessful non-management effort to elect a "Stock Trustee for Class B Stock Trust Certificate Holders." See infra, pp. 424-26.

120 Laclede Gas Co. (1952)-nominated and elected 1; Cornell-Dubilier Electric Co. (1942)-nominated 3, elected 0; Hydrauhic Press Brick Co. (1952)-nominated and elected 2; Philadelphia Transportation Co. (1952)-nominated 3, elected 1; Pittsburgh Rys. Co. (1952) -nominated 3, electěd 1; Automatic Steel Products Co. (1952)-nominated 2, elected 0; and Four Wheel Drive Auto Co.-nominated 3, elected 0. See infra, pp. 426-27. 
Adequate indication of the results of a non-management solicitation for actual control through a majority or more of the directorships is provided merely by the percentage of shares voted in favor of the non-management group. For the nine 1951 control contests the percent in their favor ranged from $13 \%$ to $72 \%$. The average and median percentages were $45 \%$ and $39 \%$, respectively, with four instances of more than a $50 \%$ vote in favor of the non-management group. ${ }^{121}$ Less success was achieved by non-management groups in 1952 when results of ten control contests ranged from $8 \%$ to $65 \%$, the average and median percentages $41 \%$ and $45 \%$, respectively, with but two instances of more than a $50 \%$ vote in favor of a non-management group. ${ }^{122}$

\section{Non-management Comment on SEC and X-14}

Management and non-management groups were invited to furnish to the writers their comments, confidential treatment being assured to them if desired. Management's comments were very few in number, appeared essentially conventional in character, and are omitted as not of probable interest to the general reader.

Most controversial among the non-management group's comments was the role of the SEC in clearing proxy soliciting material. The SEC's supporters and opponents were evenly divided quantitatively at four each. ${ }^{123}$ Its supporters found it helpful and co-operative, its opponents asserted it was not helpful and that it favored management. Inasmuch as the nonmanagement contest results were frequently less than what had been sought, it would not have been surprising if there had been a considerably larger volume of criticism of the SEC.

The remainder of the non-management comments may for convenience be divided between solicitations in which proposals are involved and those in which directorships are sought. With a view presumably to making the Rule X-14A-8 proposal provisions a more effective medium for supporting either a non-management proxy statement containing a proposal or one carrying nominees for directorships, ${ }^{124}$ it was suggested that the provision for 100 words in support of a security holders' proposal should be expanded to allow 200 words. ${ }^{125}$ It was also urged that management's re-

121 The four companies involved in 1951 non-management control contests resulting in more than $50 \%$ favorable votes for the non-management groups were: Merchants Petroleum Co., Inc. (1951), 72\%; Illinois Zinc Co. (1951), 66\%; United Cigar Whelan Stores Corp. (1951), 60\% and Twin City Rapid Transit Co. (1951), 55\%.

122 The Aluminum Industries, Inc. (1952) non-management groups drew a $53 \%$ favorable vote, and the F. L. Jacobs Co. (1952) non-inanagement group $65 \%$.

123 Cf. Wirliams, Cumulative Voting 71-72 (1951).

124 See supra, pp. 395-96 and note 68.

125 A comparable British statute permits 1,000. See British Companies Act, 10 \& 11 GEo. VI, c. $47, \S 3(1)(b)$ (as amended). 
sponse to the 100 or 200 words should be limited in "extent and character." In addition, it was also contended that management should not have the right to vote unmarked proxies in accordance with their preferences. ${ }^{126}$

In connection with contests for directorships it was urged, in view of "practical" difficulties encountered under state law in getting access to lists of security holders' names and addresses, that X-14 should be amended to provide for effective inspection of stock lists and right to copy. The stock list is crucial. Without it there is likely to be little opportunity for the non-management group to carry on any substantial personal solicitation in opposition to the considerable personal solicitation ordinarily conducted by management, its employees, and/or its paid proxy solicitors.

Inasmuch as the present X-14A-7 is designed to fill at least partially the void left by the absence of a stock list, it was also asserted that for the reasons just stated it is of obvious importance that X-14A-7 contain no loopholes and be precise with reference to the matter of when the security holders' soliciting material must be mailed by management. It was claimed that management delayed an initial security holders mailing when time was especially important. Under the present form of the rule, management must mail the security holders' material "with reasonable promptness after a receipt of tender of the material ... except that such material need not be mailed prior to the first day on which the solicitation is made on behalf of the management." It was suggested that the exception should be amended to state: . . . except that such material must be mailed at least 20 days before the meeting date.

There were a surprising number of serious charges relating to the conduct of inspectors of elections and the corporate ballot box, some dealing with alleged election fraud and others with proxy switching. It would appear that many state corporation acts do not even provide for a representative among the inspectors of the non-management group, much less for tri-partite composition consisting of equally divided members representative of management, non-management soliciting groups, and third members chosen by the adversaries' representatives. This would seem to be a fitting subject for study, for action by way of amendment of state corporation acts, and for proposals carried in non-management proxy statements and/or proposals contained in management proxy statements pursuant to $\mathrm{X}-14 \mathrm{~A}-8$.

Another complaint, one already alluded to, was the expense of nonmanagement proxy solicitations and the unequal position of non-management groups as compared to management's access to the corporate treasury. ${ }^{127}$

${ }^{120}$ See X-14A-4(b) and cf. Exchange Act Releases No. 4729. (July 10, 1952) Item 22(b) and No. 4775 (December 11, 1952), 2.

127 See infra, pp. 435-37 and supra, p. 418. 


\section{Contest Synopses}

Several brief summaries of the more significant among the 1951-1952 proxy contests under Regulation X-14 now appear in order before proceeding to conclusions. Proposal, representation, and control contests will each be noticed.

\section{Proposal Contests}

Inasmuch as proposals were employed in several of the significant representation and control contests, none but contests involving proposals alone will be considered here.

AT\&T (1952): A corporate giant, the company had assets of approximately $\$ 123 / 4$ billion, sales or receipts of over $\$ 3 \mathrm{~T} / 2$ billion, more than $1 / 2$ million employees, and over one million shareholders of record. The nonmanagement group, The Alliance of Independent Telephone Unions, held but one share of stock. It mailed its proxy statement on or about 60 days prior to the company's 1952 annual meeting by publishing it in the monthly magazines of its affiliated unions.

The union's objective was to secure adoption of its proposal to AT\&T shareholders that "stockholders . . . recommend for the consideration of the Board of Directors the elimination of the Company practice of reducing retired employees' pensions by one-half or any part of the benefits received by such employees under the Social Security Act." The union availed itself of Rule X-14A-8, as a result of which the text of its proposal and approximately 100 words in support of the proposal appeared in the manageneent's as well as the union's proxy statement. ${ }^{128}$ While the union by filing its own proxy statement was therefore in a position to solicit proxies, rather than merely to rely on favorable marking of boxes carried on the managenent's proxies, it, of course, had to confine its solicitation to those to whom it had sent or delivered its proxy statement, namely, the members of its affiliated unions who were also AT\&T shareholders. ${ }^{129}$ Consequently, only a limited amount of personal solicitation was possible.

128 The union's statement was:

"The fundaniental purpose of the Pension Plan is to solve satisfactorily the problem of retiring employees with long service records. The ultimate beneficiaries are the company and its stockholders.

"As presently administered, the Plan compels a retired employce to forfeit at lcast half of his benefits under the Federal Social Security Act. Lower paid workers, who nced every penny of their retirement benefits for inere existence in their declining years, are the ones most affected by this unjust requirement.

"The Coinpany's practice in this regard contrasts poorly with its vaunted boasts of fair treatnient to its retired loyal employees."

129 Although essentially the same proposal had been made in each of the preceding seven years and it had been carried in the management's proxy statement as apparently a "proper subject" for a proposal under X-14A-8, the company in 1952, incident to the union's initial 
The union's proposal drew considerably fewer votes, i.e. $11 \%$, than either the average of $35 \%$ or the median of $37 \%$ for 1952 proposals carried in non-management proxy statements. However, even with the limited solicitation that was possible the union's proposal received more votes than four other security holder proposals carried in the AT\&T proxy statement. While a sixth proposal in the AT\&T proxy statement received still more, this experience strongly suggests that giant and near giant corporations, i.e. those with assets of approximately one billion dollars or more, will ordinarily have so many shareholders that the expense of solicitation would place them beyond the reach of non-management soliciting groups seeking directorships. However, it also serves to emphasize the importance of the proposal rule, especially in relation to giant corporations, as a medium for shareholder participation, and indicates that an $\mathrm{X}-14 \mathrm{~A}-8$ proposal can be effectively further supported by filing a nonmanagement proxy statement and undertaking even limited proxy solicitation. ${ }^{130}$

Lawrence Portland Cement Co. (1951): The company, incorporated in Pennsylvania, had assets of over $\$ 73 / 4$ million and sales of over $\$ 81 / 2$ million. It employed 700 persons and had 1,350 shareholders of record. An Independent Stockholders Committee with headquarters on Pine Street in New York City and led by three minority directors, owned with their associates approximately $7.2 \%$ of the outstanding stock. At the previous annual meeting the three minority directors had been elected to their directorships by the votes of 175 shareholders holding about $35 \%$ of the stock outstanding.

The committee's first and only mailing, including a proxy statement, a proxy form, an objection to merger form, and a covering introductory note, was dated only 13 days prior to the scheduled special meeting in question. The soliciting material consisting of four legal-sized, typewritten pages sought proxies against (1) the management's proposed resolution authorizing the merger of the company into a subsidiary with no assets, the Dragon Cement Company, Inc., (2) the management's proposed resolution eliminating cumulative voting, and (3) the management's proposed resolution reducing the number of directors from nine to six. Under the caption "The Importance of Cumulative Voting," the committee's proxy statement ex-

effort to support further the proposal by its own proxy statement and solicitation of proxies from union members who were shareholders, attempted to omit the proposal by resorting to the procedures provided by $\mathrm{X}-14 \mathrm{~A}-8(\mathrm{~d})$. The proposal was held by the SEC, however, to be a "proper subject." Another sharply contrasting shareholder pension proposal sought a $\$ 25,000$ per annum ceiling on future pensions to officers, one officer, it heing noted, currently receiving $\$ 91,700$ as pension (see A.T.\&T. Co. 1952 proxy statement).

130 The union made the same X-14A-8 proposal and similarly filed and published its own proxy statement in 1953. 
plained that, in its opinion, the merger had no practical value to the company except to eliminate shareholder rights to cumulative voting, and that under cumulative voting a substantial minority shareholder or group of shareholders may obtain representation on the board of directors. It specifically pointed out that in the absence of cumulative voting $51 \%$ of the shareholders have complete, i.e. $100 \%$, control to the exclusion of and representation of the holders of the remaining $49 \%$. It was expressly pointed out also that at present under cumulative, voting, shareholders of the conpany owning 25,000 shares could assure themselves of one director, and that management was seeking to have this protective right surrendered. ${ }^{131}$

Under a separate caption the committee sought to overcome adverse statements attributed to solicitors for the managenent. It declared, "The Minority Directors, of course, would not and could not milk the company of its assets, fire all the present personnel or do any of the acts now being asserted by said solicitors. Our only interest lies in the welfare of the company and the improvement in the value of the stock. We have no interest in bonuses, salaries, commissions, etc. This committee does not have the funds to personally interview stockholders. Mr. . . . (the president) does because he is doing so with your money and ours. This is ouly further substantiation of our opinion that the Majority directors, in seeking to eliminate cumulative voting, are grabbing for power to perpetuate themselves in office."132 Notwithstanding these efforts and the obvious advantages to shareholders of cunulative voting, the management's proposal to merge into the no-assets subsidiary, and in so doing elininating cunulative voting and reducing directors from nine to six, carried, the committee apparently being unable to obtain the $1 / 3$ vote necessary to block the nerger. ${ }^{133}$

Representation Contests. National Airlines, Inc. (1951): This Florida corporation had assets and sales of $\$ 161 / 2$ and $\$ 241 / 4$ million, respectively, 1,900 employees and 3,000 record share owners. An Independent Stockholders Committee with headquarters on Madison Avenue in New York City and led by a director mailed its first proxy soliciting material under a date 27 days prior to the 1951 annual meeting.

131 The committee's proxy statement also made reference to the company's president's attempted $\$ 26,000$ salary and bonus increase to $\$ 100,000$ and noted that his 1950 remuneration of $\$ 74,000$ was higher than that of the president of any of the ten leading U.S. cement companies. These arguments were concluded under a caption, "Stop This Grab for Power."

132 Personal solicitation was apparently confined principally to solicitation of New York Stock Exchange and National Association of Securities Dealers inember firms to present to sharcholders the committee's views and proposals. Anticipated committee expenses were estimated at $\$ 1,000$.

$133 \mathrm{Cf}$. Similar result in the 1951 contests involving Curtis Publishing Co. and National Airlines, Inc. and see infra, pp. 425-426. 
The committee appears to have employed six mailings comprising 22 pages and consisting mostly of printed material. The first mailing contained three items: (1) a covering letter on the letter head of William $\mathrm{K}$. Jacobs, Jr., the committee's chairman-director, ${ }^{134}(2)$ an enclosed bulletin stating the committee's views, and (3) an enclosed card for expressing agreement with the committee, the name of the agreeing person, and the number of shares he held or represented. The bulletin enclosure was a six page printed document issued over the names of the three committee meinbers. It was, as indicated on its cover page, a "WARNING" against the threefold "Threat" to shareholders of three management proposals to be voted upon at the approaching annual meeting: (1) elimination from the certificate of incorporation and the by-laws of the provision for cumulative voting, (2) elimination similarly of the provisions requiring a $2 / 3$ vote of shareholders or directors to ainend the by-laws and substitution of a new by-law permitting their amendment by only a majority vote of the directors, and (3) giving to directors unrestricted authority by majority vote to dispose of over $1 / 2$ million common shares previously authorized to be issued for a specific purpose. Each of the three "threats" was explained individually. The proposal to abolish cumulative voting was here, too, described as "A Grab for Power," timed in this instance with the close of the first fiscal year in the company's fourteen year history when it had paid a dividend. While no proxy as such was expressly sought, the purpose of the first mailing is clear from a closing sentence which stated: "Before undertaking the expenditure of time, energy, and money required in a proxy contest, we would like to know that you, as a stockholder, agree with our views." $" 135$

The second committee mailing, dated about two weeks later and mailed about two weeks prior to the annual meeting, consisted of eight printed pages, excluding attachments, designated five candidates for minority directorships on the 11-man board, and sought a red, white and blue proxy in support of the committee's opposition to the management's three proposals and in support of the five minority nominees. It supplemented earlier arguments and in addition, replied to management comments at length. It also reflected the committee's employment of a paid proxy soliciting firm, and the chairman's intention to request members of the New York Society

184 The chairman-director's one page covering letter dealt only with cumulative voting, and further identified him as a member of the New York Society of Security Analysts. It was a concise and comprehensive statement in favor of cumulative voting and closed with the sentence: "As a respected member of the financial commumity to whom investors turn for advice and guidance, you could render an important service to stockholders generally by making clear to any stockholder known to you the true purpose and effect of the management's proposal."

135 The mailing was of course a solicitation under the $\mathrm{X}-14 \mathrm{~A}-1$ definition, and required to be filed pursuant to $X-14 A-3$ and $X-14 A-6$. Enclosed witl the bulletin as a part of the committee's first mailing were two items from the American Aviation Daily, August 24, 1951, p. 355 . 
of Security Analysts and New York Stock Exchange member firms to present to shareholders the committee's views with respect to cumulative voting. ${ }^{136}$ The committee's third mailing was Financial Editor Robert P. Vanderpoel's column from the Chicago Sun-Times of September 7, 1951 and headlined "Nat'l Airlimes Stockholders Asked to Sign Away Rights." The other "mailings" were copies of telegrams.

At the annual meeting, which lasted nine hours, $83 \%$ of the outstanding , shares were represented. Three of the five minority noiminees were elected directors, but cumulative voting was eliminated with the result that unless the committee could garner considerably more votes in a subsequent contest it had no prospect for re-electing its three directors. ${ }^{137}$

Four Wheel Drive Auto Co. (1952): The company was incorporated in Wisconsin. It had assets and sales of nearly $\$ 17$ and $\$ 18$ million, respectively, 2,000 enployees and 1,332 record owners. The non-management soliciting naterial was filed by a Chicago securities broker-dealer, whose first mailing was effected only 6 days before the 1952 annual meeting.

The first and only nailing opened with the contention that independent directors were necessary if the company was to be operated to produce dividends for shareholders rather than bonuses for officers. In its first three and a half pages it complained also of the nuanagement's poor operating record of having earned in the preceding five years of high business activity less than $1 \%$ on its sales, of having in 1949 and 1950 lost money $(\$ 649,000)$, and of having paid no dividends in the last four years while paying large officer bonuses in each of the years. There followed a six year summary table of net earnings, dividends paid, total bonuses paid, and officers' and directors' bonuses. Other charges involved the refusal of the right of inspection though it is provided for by Wisconsin law, the use of the stagger system ${ }^{138}$ in electing directors, and management's employment of a paid proxy soliciting firm. Three nominees, two business men and another securities broker-dealer, were proposed for the three open directorships on the mine-nian "staggered" board.

Approximately $90 \%$ of the stock was represented at the annual meeting. The non-nuanagement nominees received 129,000 votes while management nominees received 140,000 votes. However, 24,000 votes were thrown out, and the non-management group received proxies for 5,000 shares too late to cast them in their favor, leaving a total of 29,000 votes shrouded in doubt. Inasinuch as management obtained a vote of but 11,000 more than

${ }^{136}$ An attached clipping from the New York Herald Tribune of September 7, 1951 was headlined "National Airlines By-Law Plan Aims to Oust Single Director."

The management did not furnish any of its proxy material to the survey.

13. Approximately 5 to $10 \%$ of National Airlines stock was owned by Investors Mutual, Inc., an investment company.

138 Wisconsin has no provision for cumulative voting. 
the non-management group, less than half of the excluded 29,000 could have meant election of all three non-management minority nominees. ${ }^{139}$

Control Contests. United Cigar Whelan Stores Corp. (1951): The company had assets and sales of $\$ 28 \mathrm{I} / 4$ and $\$ 74 \mathrm{~T} / 4$ million dollars, respectively, 5,000 employees and 11,620 shareholders of record, and was and is a Delaware corporation. Heading the non-management solicitors was Charles Green, a New York City electrical appliance dealer and participant in the earlier Twin City Rapid Transit Co. proxy contests. During the 1951 summer vacation period he solicited and obtained demands for a special meeting of United Cigar shareholders.

The purpose of the demanded special meeting was to remove and replace all 12 directors and to make an audit of the company. Green conmenced soliciting proxies in support of these two proposals and his 12 nominees 31 days prior to the day set for the special meeting. Management had asserted the then current two year declime in sales, earnings and margin of profit had been due to the closing up of unprofitable units. A purpose of the proposed audit was said to be to check the nianagement's statement, particularly because of the absence of dividends to common stockholders. The asserted absence of any "concrete policy" was a further basis for the proposed renoval and replacement of directors. The nonmanagement group and their nominees owned $8 \%$ of the company's stock, gave notice of intention to employ a paid proxy soliciting firn, and opmed that "Stockholders are the forgotten individuals of private enterprise until they make themselves heard through proxies."

In all, Green used 5 mailings totaling 16 pages of printed material in soliciting proxies for the special neeting. His second nuailing, comprismg 4 pages and dated about $2 \mathrm{I} / 2$ weeks before the meeting, undertook to respond to some six eharges against him by management, including the characterization of him as a "proxyteer." He then proceeded to discuss such topics as: (1) Future store operation and location, (2) persomel selection and training, (3) buying, (4) inventory stock control and maintenance, (5) sales promotion, advertising, and display, and (6) food and soda fountain operation, concluding "I say We Need This Management Changed NOW." In a third mailing dated a week later he undertook refutation of a managenent "SMEAR CAMPAIGN" agamst him, asserted that the real issues had nothing to do with any individual or personality, and challenged managenient to account for: (1) 13 years of poor management, (2) declining profits in every year since 1946- "Before and after taxes," (3) poor use of retained profits so that by 1950 earnings were very much lower than in 1942, (4) no dividend return to stockholders, (5) large sal-

130 See for results Wall Street Journal, September 11, 1952, p. 13, col. 1. False statements by management were also alleged im an effort to set aside the election. 
aries and bonuses despite declining profits and zero return to stockholders, and (6) deterioration in market price of stock since 1946. Green then discussed the company's food department in terms of proper physical installations and merchandising. The fourth mailing by Green was devoted to his participation in the Twin City contests, and consisted largely of a quote from a court reporter's transcript of a statement by a Detroit Probate Court Justice concluding, "Charlie, from my way of thinking you have done a good job (at Twin City Rapid Transit Co.)!"

Collier's Magazime for September 22, 1951 carried a box announcement with red print captions, the first of which read, "The Public Be Damned!" "The text below referred to a "promoter" who won control of Twin City, "fell out with his partners and lost control," and "Gangsters began infiltrating the company." It closed with "Undaunted, the promoter is currently maneuvering to gain control of the United-Whelan Stores Corporation with its national chain of cigar and drug stores." In large letters the Collier's ad urged, "Don't Miss-How Mobsters Grabbed A City's Transit Line." ${ }^{140}$ Both the Collier's box and subsequent article ${ }^{141}$ contrasted sharply with the Kefauver report comment on Twin City which read: "The twin cities of Minneapolis and St. Paul, Minn., were recently rocked by evidence showing that the hoodlum element had nearly succeeded in taking over the Twin City Rapid Transit Co. Fred Osanna, a lawyer for and director of this company, led an almost successful fight to oust the present management. Fortunately, the company's president, Charles Green, discovered just in time that Osanna was associating with such notorious hoodlums as Kid Cann." 142

Collier's box ad and the text of the Collier's article, present interesting questions as to whether their use in proxy soliciting material would have been misleading and unfair within the meaning of Rule X-14A-9. In any event they were not circulated to shareholders. ${ }^{143}$ Subsequently, Green sued Collier's for $\$ 250,000,000$ in New York Federal Court alleging libel based on the box ad and article. ${ }^{144}$

Green's group commanded a substantial majority of the shares voted, $1,010,711$, to 598,382 for management, but it did not obtain the requisite majority of all shares outstanding required under Delaware law because the meeting was a special rather than an annual meeting. However, since the vote secured would have been enough if repeated at the May 1952

140 See 128 Collier's 58 (September 22, 1951).

141 The article will be found at 128 Collier's 30 (September 29, 1951).

142 Throp Interor Report of the Spectal Conamittee to Investigate Organyzed CrIme IN Interstate Comarerce, 82d Cong., 1st Sess., Senate Rep. No. 307 (May 1, 1951) 176.

${ }^{143}$ Cf. N. Y. Journal American, September 17, 1951, p. 10, col. 2.

144 Cleveland Plain Dealer, November 24, 1951, p. 34A, col. 6 . The case is still pending in New York Federal Court. 
annual meeting, a compromise was negotiated. ${ }^{145}$ Under the compromise Green gained seven of the 12 directorships. ${ }^{146}$

F. I. Jacobs Co. (1952): A Michigan corporation, this company had $\$ 111 / 4$ million in assets and $\$ 201 / 4$ million in sales. It employed 2,400 persons and had 2,466 shareholders of record. Non-management proxy soliciting material was filed by the F. L. Jacobs Co. Stockholder's Protective Committee with headquarters on Fifth Avenue in New York City, the first mailing being dated 114 days prior to the approaching annual meeting.

In its initial mailing, under the chairmanship of a New York City lawyer, the committee reported the resignation of the company president, allegedly to escape committee charges of mismanagement, and his replacement by his brother. It also pointed to the dismissal by the company of its sales staff of 39 years' standing and the hiring of an outside sales organization, and management's engaging of a business consultant organization to tell them what was wrong and how to correct it. Beyond this the letter merely asked shareholders "thoughts or suggestions" as to whether shareholder action was indicated. Five more mailings were to follow, the six consisting in all of 19 pages of primted material.

The committee's second niailing dated October 16, 1952, reported accord from more than $50 \%$ of the shares outstanding to support its efforts. It also advised that it had just learned that the "outside" sales organization which management had employed upon the dismissal of its sales staff was a newly formed corporation organized by the resigned company president. Lucrative drawing account and commission clauses were described. Negotiations with incumbent directors, the committee said, had resulted in merely a "listeming post" offer of two seats on the board of directors, and the announced intention of removing the entire "Mismanagement" at the annual nreeting was declared. Share ownership and identifying data concerning the conmittee nuembers was stated. In addition, the committee also asserted: "We wish to go on record at this time by stating that in the event we are successful in removing the present Mismanagentent, none of the members of the Stockholders' Protective Committee expects to take any kind of a job with the Company. We are not looking for jobs." The third mailing dated November 7, 1952, reported that management had authorized the signing of a three year contract with an individual as an executive of the Conipany at a salary of $\$ 50,000$ a year plus a bonus of $\$ 7,500$ for his accepting, and that nranagenient intended to elect him president.

The committee's fourth nailing was its proxy statement in support of its nominees for directorships, the initial mailing having been merely a proxy statement covering an attempt to secure shareholder indications of

145 Cleveland Plain Dealer, October 9, 1951, p. 16, cols. 1 and 2.

146 Wall Street Journal, October 18, 1951, p. 6, col. 3. 
interest in undertaking committee activity. Physically its nominee proxy statenient was both convenient in size, being of pocket proportions, namely, 3 by $8 \mathrm{r} / 2$ inches rather than the conventional letter-size document, and in addition it was illustrated with interspersed cartoon-type drawings to support the text. Moreover, this two-step proxy statement procedure served to protect the nominees from management campaign literature attack and manageinent-pressured withdrawals of nominees prior to the last few weeks of the contest. The nominee statement, dated one month before the annual meeting, showed the nominees and committees as owning only $.3 \%$ of its stock. It included, in addition to the usual descriptive data, captions and text on "Why You Should Vote," and "How to Vote." Notice was also given of the committee's employment of a paid proxy soliciting firm.

Two more mailings followed, one dated November 26, 1952, the other December 2, 1952. The first was "The Story of the Seven Lean Years and the Seven Fat Years-A Parable," dealing with the years 1946-1952 in which the automobile industry enjoyed prosperity, but in which the company had an aggregate loss of $\$ 7 / 4$ million while the Jacobs brothers were personally prospering from their company salaries and bonuses.

The final mailing was of near atomic proportions. Dated December 2, 1952 , it reiterated the $\$ 7 \mathrm{I} / 4$ million seven year loss and the Jacobs brothers' $\$ 367,000$ salaries and bonuses in the same period. It then set forth an exact quote from a report prepared by the General Accounting Office of the United States which, in part, was read into the transcript of hearings of the Fulbright Subcommittee of the United States Senate, by Senator Paul H. Douglas. It stated that "Major questionable practices of the F. L. Jacobs Co. resulted in the following excessive costs to the war effort" and showed 11 items totaling $\$ 5 \mathrm{I} / 4$ million. Also listed were two more items of $\$ 10$ million for Jacobs' profits on subcontractors' operations and $\$ 120,000$ for miscellaneous kick-back violations. Several paragraphs were also devoted to the 1950 company loan of " $\$ 120,000$ to E. Merl Young (of the Washington mink coat fame), with no security whatsoever for his personal use in a private speculative venture in which Rex Jacobs was a secret participant and in which Clare Jacobs subsequently joined.".147

Results of shareholder voting were the election of six of the committee's seven nominees for directorships, with $87 \%$ of the shares voting.

Aluminum Industries, Inc. (1952): Assets and sales here were $\$ 71 / 2$ million and $\$ 13 x / 4$ million, there were 1,350 employees and 628 shareholders

147 The company's loan to E. Merl Young was disclosed pursuant to X-14's Schedule 14A Item 7, in the F. L. Jacobs Co. 1951 and 1952 management proxy statement. For post proxy contest developments see, Victory But No Peace, Wall Street Journal, April 13, 1953, p. 16, col. 1-3, and F. L. Jacobs Holder Group Wants Company Put in Receivership, Wall Street Journal, Mar. 25, 1953, p. 3, col. 1 . 
of record, and the company was and is an Ohio corporation. Two nonmanagement soliciting committees divided the area of solicitation by agreement. The so-called Benjamin committee with offices on Madison Avenue solicited in the New York City area and the Stockholders' Protective Committee of Cincinnati concentrated on areas other than New York City.

This contest is of interest because one of the issues in the contest was the company's prior policy of avoidance of the SEC's proxy rules by the device of non-solicitation. That is to say, the company in other years simply gave notice of the loolding of its annual meeting, filed no proxy statement and solicited no proxies with the result that virtually no shareholders were offered an opportunity to vote, and thereupon management either voted its own management nominee mto office by means of the management lioldings or declared the manageinent incumbents continued in office for want of a quorum to elect their successors. ${ }^{148}$

The two committees employed four mailings consisting of eight printed pages, the first of which was mailed 35 days before the 1952 annual ineeting. In its opeming proxy statement the protective committee asserted that "the management control of the Directorate of your Company which exercises $100 \%$ of the operational control of your Company, represents less than $35 \%$ of the stock interest or ownerslip of your Company and was chosen at an annual meeting at which proxy representation of all shareholders was not solicited by management." Complaint was also made of net profit of only one per cent of sales, a ratio of current assets to current liabilities close to a life insurance company's restrictive dividend-loan provision, and management salaries im excess of dividends to shareliolders. Committee nominees' and members' security holdings amounted to nearly $22 \%$.

In a second mailing a matter not covered in the first was touched on, the management's employment of a firm of paid proxy solicitors. The third mailing simply summarized the' protective committee's answers to three main issues: compliance with SEC proxy regulation-a contrast with the company's prior policy of avoidance, cooperation with the Benjamin committee to designate sliareholder-elected directors, and the policy of the committee that none of its members would accept any salaried position with the company. The Benjamin committee's proxy statement interjected no additional issues.

Approximately $95 \%$ of the slares were voted, $53 \%$ of them in favor of the committee with the result that they won six of the 11 directorships.

\section{CONCLUSION}

A number of myths and misconceptions have clouded consideration of the position and potential of proxy contests in our economic democracy.

${ }^{148}$ See Emerson and Latcham, supra note 5, and Bayne, Around and Beyond the SECThe Disenfranchised Stockholder, 26 IND. L. J. 207 (1951). 
Not the least of these is the commonly expressed feeling that there are too many proxy contests. But this assertion does not square with the facts, for as has just been seen, it simply is not true that non-management groups are using X-14 as an instrument for proxy contest harassment of management. ${ }^{149}$ Moreover, the number of actual contests for control is a small proportion of all X-14 contests. ${ }^{150}$ Similarly, the assets, ${ }^{161}$, sales, ${ }^{162}$ and number of persons employed ${ }^{153}$ by companies affected by $X-14$ proxy contests clearly demonstrates that neither the nation's productive facilities, ${ }^{154}$ gross national product, ${ }^{155}$ nor the objective of full employment ${ }^{156}$ is even slightly affected by any disruptions resulting from proxy contests.

As already noted, the writers, in connection with an earlier proxy contest case-study, suggested that X-14, through proxy contests, actually gave promise of making an effective contribution to our society by either stimulating present management to provide, or affording a medium for securing elsewhere, the vigorous and faithful corporate leadership so essential to the growth and survival of our capitalistic system. ${ }^{157}$ In other words, here was a corporate regulation and technique which could serve as a counterpart to the essential political check so important to national balance-a technique in a corporate context for "turning rascals out" or inspiring them to follow a more enlightened course. Yet a well known proxy soliciting firm, which usually serves management clients, recently stated to its clientele and subscribers "proxy contests ... are always harmful."168 The obvious over-generalization implicit in the word "always" should of course, serve at the outset to caution a discriminating reader, but in fact even a presumption that proxy contests are generally harmful would clearly be at war with the results of the survey just completed. To the contrary, the survey reveals that proxy contests are almost invariably the result of poor or decadent management if not actual imsmanagement. ${ }^{169}$ And the proxy sohiciting firm just referred to indicates implied awareness of this, as is illutrated by its endeavor, in addition to proxy solicitation, to foster sound "Trends in Management-Stockholder Relations"160 and its suggestion that

149 Supra pp. 399-400.

150 Supra pp. 415 and 420.

151 Supra pp. 400-02.

152 Supra pp. 402-03.

153 Supra pp. 405-06.

154 Supra p. 402.

155 Supra pp. 403-04.

156 Supra p. 406.

157 Supra note 1 at 430. Cf. Solicitation of Assents to Railroad Reorganization Plans under Section $20 b$ of the Interstate Commerce Act, 62 YaLE L. J. 806 (1953).

168See Georgeson \& Co.'s Trends in Management-Stockholder Relations (June 1953), 1. 159 Supra pp. $416-417$.

160 Supra note 157 . 
"The more extreme cases (of failure to keep stockholders frankly informed) result in (the) proxy contests" which it and some others say are "always harmful." But, as shown by the present survey, proxy contests are the result not merely of failure to keep shareholders frankly informed. They are caused more specifically by poor or decadent management or "mismanagement" 161 which, even given a high degree of frankness, is hardly a matter that can be expected to be directly reported to shareholders. It would seem therefore, that it would not be too much to assert that for the purpose of removing poor or decadent management, a proxy contest camiot but help to be beneficial. Even if the self-appointed outside group should actually include a "proxyteer," 162 it may well be that the initiative he may be expected to possess is at least as desirable, if not somewhat preferable, to an incumbent, decadent management operating the company at a loss, or with profits too small to permit reasonable dividends. ${ }^{163}$ Further, even if the newcomers prove to be incompetent managers the contest may be beneficial in that it may rid the shareholders of a then current blight. And the contest may afford the stockholders sufficient experience to enable them to eventually install competent leadership.

It should be observed, however, that fear of embracing a "proxyteer" or a new rascal is something of a twin to the myth and misconception regarding proxy contest harmfulness and frequency, though a twin which has found expression in highly respected academic quarters. Recently another writer stated, "Too often, when stockholder groups do step forward to propose board candidates in opposition to the management slate, the motives of the opposition leaders are properly subject to suspicion by their fellow stockholders." 10 Now, suspicion is an evil as incompatable as its sister fear to a free and democratic society. Moreover, if one is to be allowed the "indulgence" of suspicion of an insurgent non-management group, is there not then ground for at least an equal suspicion of an incumbent, decadent management? And is it not better, in any event, and indeed more democratic, to eliminate suspicion by hearing out all sides and by examining carefully their respective experience records and programs for company improvement and progress?

Nevertheless, the Wall Street Journal early this year in a front page lead item under the captions "Business Bulletin" and "A Special Background Report on Trends in Industry and Finance" presumed to forecast, though somewhat guardedly, that "Proxy Battles may be numerous and bitter in 1953." 165 It concluded, "Some insurrections are the natural re-

\footnotetext{
161 Supra pp. 416-17 and pp. 429-30.

162 Supra p. 427.

103 Writams, Cuarulative Votmg 78-81 (1951).

104 IVilliams, VA. L. WeEr. Dicta, Vol. V, No. 20 (1953).

165 Wall Street Journal, Jan. 22, 1953, p. 1, col. 6.
} 
actions to poor profit showings. But a number are deliberately plotted attacks by ambitious men who are looking around for vulnerable and potentially lucrative situations." 166 The record to May 1, 1953, which covers virtually all the filings relating to the 1953 primary "proxy season," 167 however, shows that in 1953 only 11 non-management proxy statements had been filed under Regulation X-14 as compared with 13 and 17, respectively, to the same date in 1951 and 1952. While one of the 1953 contests was led by an individual who had been a participant in proxy contests in recent prior years, ${ }^{168}$ it is not apparent that either this or other 1953 contests have been any more bitter than those of other years, the Wall Street Journal to the contrary notwithstanding. As has already been implied, improperly ambitious inen, whether they be proxyteers, rascals, or others, are of course always to be deplored, but are in this age an apparently inescapable phenomena of both dictatorship and democracy. Even so, ambition directed at so-called "vulnerable and potentially lucrative situations" would actually seein highly apt to be aimed at poor or decadent management, the economic and social blight which, as noted, is and has been the prime inotivation for proxy contests.

Other conclusions are suggested with reference to the data secured in regard to matters other than the number of filings, assets, sales and employees. The presence of mandatory cumulative voting, for example, has not precipitated proxy contests under Regulation X-14, for, as has been seen, approximately half of the contests involved companies incorporated in states where cumulative voting was merely permissive. ${ }^{160}$ While only one contest concerned a corporation chartered in a state with no provision for cumulative voting, Wisconsin, this result would seem to be explained by the situation that cumulative voting is provided for on one basis or the other in virtually all industrially and commercially important states.

The most significant aspect of the data relating to shareholders of record is undoubtedly the indication that investment companies ordinarily were not a significant factor in proxy contests under X-14, primarily for the simple reason that they held little or no stock in the companies involved. ${ }^{150}$ On the other hand, in the one instance, the 1951 National Airlines, Inc., contest, in which an investment company, Investors Mutual, Inc., was ap-

166 Wall Street Journal, Jan. 22, 1953, p. 1, col. 6.

167 Supra note 5; Emerson and Latcham, 59 YALE L. J. at 675.

168 For reports re 1953 Twentieth-Century Fox Co. contest led by Charles Green of New York City, see Wall Street Journal, March 28, 1953, p. 4, col. 4; April 7, 1953, p. 15, col. 2 ; April 8, 1953, p. 2, col. 4 and April 17, 1953, p. 6 col. 4. Cf. Wall Street Journal, March 26, 1953, p. 5, col. 3, re Mr. Green's inclusion on the U.S. Hoffman Machinery management slate led by the Chairman of the New York State Republican Committee.

169 Supra p. 409.

110 Supra pp. 409-11. 
parently in a position to provide shareholder leadership, it made no effort to state its position publicly on a basic issue of vital importance to shareholders: cumulative voting. Its failure in leadership, moreover, was in striking contrast to the forthright Chicago Sun-Times column by Financial Editor Robert P. Vanderpoel and the similar participation in support of cumulative votmg by members of the New York Society of Security Analysts, Inc., in the same 1951 National Airlines proxy contest. ${ }^{171}$

The objectives, i.e., the issues and subjects, involved in proxy contests contrasted sharply with the subjects of proposals previously found to have been submitted under Rule X-14A-8 for inclusion in management's proxy statements. As shown elsewhere X-14A-8 proposal subjects dealt primarily with what might be described as the politico-organizational aspects of corporations, namely, such matters as cumulative voting, post-meeting reports, meeting place, etc. ${ }^{172}$ Issues and subjects of proxy contest, on the other hand, related.principally to management-economic aspects, such as manageinent's and directors' activity and compensation, dividends, etc. ${ }^{173}$

Personal solicitation, and the securing under state law of a stock list to make possible effective personal solicitation is obviously vital. ${ }^{174} \mathrm{Ex}$ penses, another important lever operating on personal solicitation, were, from the standpoint of the average small investors, found to be of a substantial amount, $\$ 7,077$ to $\$ 10,652$ on the average. ${ }^{175}$ However, such expenses are actually small from the vantage point of financiers; wealthy private investors, and large entrepreneurs undertaking to acquire control of additional corporate operations. From either standpoint, however, a nonmanagement group was clearly unequally situated as compared to incumbent management judicially fortified in its recourse to the corporate treasury to finance its proxy solicitation. Elsewhere, the writers have noted a recent case, and there is now another in accord, sustaming the right of successful non-management groups to reimburse themselves from the company treasury. And the writers have urged that the same logic calls for nonmanagement groups' reimbursement, without regard to their contest success or failure, if the vote cast in their favor should equal some minimum percentage of shares voted, such as say, 10 or $15 \% .^{176}$ Alternatives to a fixed percentage basis for reimbursement, however, also are quite plausible, for example, some form of proportional reimbursement.

1T1 Supra p. 426 and see Vanderpoel, The Analyst and the Financial Press, 9 THE ANALYsts Journal 104 (June 1953).

172 Supra note 85 and note 10.

173 Supra pp. 416-17.

174 Supra p. 418.

175 Ibid.

170 Supra note 14. 
Under proportional reimbursement ${ }^{177}$ for proxy contest expenses recovery would be allowed on the basis of the following formula (with $\mathrm{X}$ representing non-management expenses allowed):

Management expenses allowed $\mathrm{X}$

Votes secured by management $=\overline{\text { Votes secured by non-management }}$ but in no event allow more than actual expenses. The rationale, of course, for proportional reimbursement is that in fairness whatever management spends to secure a vote should be allowable to the non-management group properly to secure a vote. If the management makes exorbitant expenses, it increases the proportion as a basis for allowance of expenses of the competing non-management committee. However, reasonable checks are maintained, for the number of votes secured by the non-management group will be dependent upon the merit in the shareholders' opinion of their issues and subjects, and also of the caliber of their candidates for directorships. This formula may be expected, therefore, to operate to prevent so-called "crackpots" from casually tapping the corporate treasury. In addition, the expenses of the non-management group are curbed relatively under a proportional formula, because they at least may not be any more spendthrift pro rata than management. As a practical matter, even under the formula management still has a substantial advantage by virtue of its position of frequently being able almost effortlessly to put a sizable block of votes in its pocket, due to its friendly relationships with securities broker-dealers, bankers, institutions, suppliers, distributors, employees, pensioners, etc. However, under the proportional formula no reimbursement should be allowed in any event for votes procured by either group by means of its own pressure soliciting tactics. ${ }^{178}$

The results of voting and expenses of solicitation in the contests surveyed militate strongly in favor of reimbursement either on a minimum percentage or proportional basis. If these techniques seem drastic there is yet, however, the proposed alternative of requiring management to include the non-management nominees and/or proposals in the opening management proxy statement along with the management nominees and its proposals, and making equal provision for voting for any of them by means of appropriate boxes carried in the management's form of proxy. ${ }^{170}$ It has been suggested that to include both slates in the proxy form would present a

177 The writers are indebted for the suggestion regarding proportional reimbursement to Hastings P. Baker, Esq., of New York City.

178 Supra note 1 and note 16.

179 See SEC Exchange Acr Rerease No. 3347 at 2 (Dec. 18, 1942); Illinois Central R.R. Co. 1949 management proxy statement; and Caplin, Proxies, Annual Meetings and Corporate Democracy; The Lawyers' Role, 37 VA. L. Rev. 653 (1951), and Caplin, Shareholder Nominations of Directors: A Program for Fair Corporate Suffrage, 39 VA. L. Rev. 141 (1953). 
tabulation problem, especially in respect of large corporations, as a consequence of asserted impossibility of designing a mechanical tabulator capable of computing in volume the results of such plural voting. Considering the mechanical tabulating niarvels of the day and with nrathematicians and engineers of the mechanical tabulating nrachines available this contention would seem to call for careful reconsideration.

There reniain for consideration several psychological and social factors generally not dissinilar froin the over-frequent, always harmful, and besuspicious-of-non-nranagenient-groups contentions regarding proxy contests. One is the point of view, also used in opposition to cumulative voting, that the managenent and operation of a corporation requires nothing less than harniony froin all shareholders and all directors, that proxy contests destroy harmony, and that therefore they present a clear corporate danger. As has been pointed out by another writer, our local and national election contests have not been destructive of our society, and operating a corporation is no niore complex than manning government. ${ }^{180}$ Indeed, the general success we have achieved in the political field would seem to argue strongly for further interjecting criticism and free discussion into corporate life as a desirable instrument for its progress. Shareholder deniocracy, i.e., fuller shareholder participation, therefore holds promise for affording a broader outlook for corporations-far beyond what any limited number of men, whether management or otherwise engaged, could hope to envision. In an econonic context the discussion-criticisin motivation appears as conipetition, an ingredient widely-heralded as fundamental to the capitalistic system. As we employ competitive techniques in the econoiny there would seem to be no valid reason for exenipting inanagenient from competing with other potential managers for the privilege of continuing to function in a inanagement position. Like ideas and truth, managenient would presumably be the stronger for having by its ideas and activities to compete presently or potentially for the opportunity to serve shareholders and the public generally.

Yet another assertion commonly emanating from manageinent quarters in opposition to shareholder mobilization is the insistence that successful management involves an undefinable quality apparently comprised of carefully developed potions of savoir faire, fitness extraordinary, etc., all of so rare a degree as to be essentially incomprehensible to the shareholder spectator or others outside management. Inasmuch as this sort of argument remains to be documented, it does not seem unfair to note that there is, however, a decidedly different school that has found expression in a recent book, also undocumented and entitled "How to Succeed in Business With-

180 Gilbert, Wanted: $A$ Program for Fair Corporate Suffrage, 4 Investor 28, 34 (June 1953). 
out Really Trying." Although merely narrative in form, this effort points significantly to the easily recognized "success-making" phenomena of the busmess world..$^{181}$

Finally, there is the shopworn idol that it is extremely undesirable to change from management experienced with the company's affairs. The terse answer here is that, quite apart from proxy contests, there is already with us rapidly growing executive turnover in any event. ${ }^{182}$ And, as far as can be determined it appears clear that, generally, management vacancies are filled very nearly as rapidly as they develop and usually at no perceptible loss. Not infrequently a nearly equally competent newcomer is even paid a substantially smaller salary, a saving thus being achieved.

As suggested by this article's title, "Proxy Contests: A Study in Shareholder Sovereignty," contests for proxies are but an expression of the shareholder's traditional and historic corporate sovereignty. ${ }^{183}$ Rooted like Thomas Jefferson's political popular sovereignty in the common sense of the common man, the ultimate person who must be relied upon for decision is the common or general shareholder. And if he is to make intelligent decisions, the shareholder inust be given sufficient information. The voice of the stockholder, ${ }^{184}$ however, must be heard froin not only in proxy contests, which are relatively rare, but also in the general operation of the corporation, through the proposal rule, and otherwise, for more complete participation by the shareholder will increase his sense of ownership in our economic system, and will benefit management by affording it diversity of opinion and criticisin so necessary for healthy growth.

181 MeAd, How to Succeed IN BusmNess Without RearIy TrYING (1952).

182 Booz, Atren \& Hajurton, The Growing Probiem of Executtve Turnover (1953). 183 Supra note 14.

184 For an editorial commenting favorably on the 1953 increased shareholder participation, see Wall Street Journal, May 22, 1953, p. 4, col. 1. 